\title{
Catalytic activity of metals in heterogeneous Fenton-like oxidation of wastewater contaminants: a review
}

\author{
Sajid Hussain ${ }^{1} \cdot$ Eleonora Aneggi $^{1}$ (D) Daniele Goi ${ }^{1}$
}

Received: 18 December 2020 / Accepted: 15 January 2021 / Published online: 14 February 2021

(c) The Author(s) 2021

\begin{abstract}
Innovations in water technology are needed to solve challenges of climate change, resource shortages, emerging contaminants, urbanization, sustainable development and demographic changes. In particular, conventional techniques of wastewater treatment are limited by the presence of poorly biodegradable organic matter. Alternatively, recent Fenton, Fenton-like and hybrid processes appear successful for cleaning of different types of liquid wastewaters. Here, we review the application of metallic catalyst $-\mathrm{H}_{2} \mathrm{O}_{2}$ systems in the heterogeneous Fenton process. Each metallic catalyst $-\mathrm{H}_{2} \mathrm{O}_{2}$ system has unique redox properties due to metal oxidation state. Solution $\mathrm{pH}$ is a major influencing factor. Catalysts made of iron and cerium form stable complexes with oxidation products and $\mathrm{H}_{2} \mathrm{O}_{2}$, thus resulting in reduced activities. Copper forms transitory complexes with oxidation products, but copper catalytic activity is restored during the reaction. Silver and manganese do not form complexes. The catalyst performance for degradation and mineralization decreases in the order: manganese, copper, iron, silver, cerium, yet the easiness of practical application decreases in the order: copper, manganese, iron, silver, cerium.
\end{abstract}

Keywords Fenton process $\cdot$ Heterogeneous $\cdot$ Catalyst $\cdot \mathrm{H}_{2} \mathrm{O}_{2} \cdot$ Oxidation $\cdot$ Wastewater treatment $\cdot$ AOP

\section{Introduction}

Over the past few decades, the massive industrialization and urbanization has triggered an enormous stress on the environment. Water being the fundamental pillar of the environment has been affected the most, and numerous organic pollutants are being detected in ground- and surface waters. Water contamination has raised an alarm for the scientific community because it has serious consequences for the humans as well as to the ecosystem (Kolpin et al. 2002). To safeguard standard quality, it is crucial to carefully manage this precious resource, especially in the face of the current challenges: climate change, population growth, urbanization and pollution. Innovations in water technology are fundamental in finding solutions to these essential issues. A key feature is the pollution of anthropogenic origin constantly introduced in the environment (Bokare and Choi 2014). Nowadays, more than 700 emerging pollutants,

Eleonora Aneggi

eleonora.aneggi@uniud.it

1 Dipartimento Politecnico Di Ingegneria E Architettura, Università Di Udine, via del Cotonificio 108, 33100 Udine, Italy their metabolites and transformation products, are present in the European aquatic environment. The list of emerging compounds and chemicals is significantly large and continuously growing with the introduction of new commercial compounds, disposal of chemicals and further identification of new molecules that includes pharmaceuticals and personal care products (PPCPs), pesticides, endocrine-disrupting chemicals (EDCs), industrial chemicals, surfactants and antibiotic-resistant bacteria (Gavrilescu et al. 2015). Conventional treatment processes (sedimentation and biological treatment) are not capable of removing these micropollutants, and thus innovative technologies are required (Chan et al. 2009; Glassmeyer et al. 2005; Gogate and Pandit 2004; Kasprzyk-Hordern et al. 2008; Kim et al. 2007; Metz and Ingold 2014; Quinn et al. 2008).

Advanced oxidation processes (AOPs), have been proven effective when it comes to deal with persistent organic pollutants (Andreozzi et al. 1999; Bello and Raman 2019; Boczkaj and Fernandes 2017; Glaze and Kang 1989; Mousset and Dionysiou 2020; Rueda Márquez et al. 2018; Salimi et al. 2017; Wang and Zhuan 2020). These processes generate temporary species, fundamentally hydroxyl radicals $\left(\mathrm{OH}^{\bullet}\right)$ which attack the targeted pollutants and oxidize them (Fakhru'l-Razi et al. 2009; Ioannou et al. 2015; Shahidi et al. 
2015; Tiya-Djowe et al. 2016). The key features which make these processes superior to other processes are their ability to be operated near ambient conditions, nonselective nature of $\mathrm{OH}^{\bullet}$ radicals and conversion of pollutants into nontoxic products such as $\mathrm{CO}_{2}$ and $\mathrm{H}_{2} \mathrm{O}$ (Neyens and Baeyens 2003). Advanced oxidation processes can also be integrated with existing biological processes as a pretreatment strategy for the treatment of heavily polluted wastewater streams (Oller et al. 2011).

There are several types of advanced oxidation processes based on the mechanism of $\mathrm{OH}^{\bullet}$ generation: for instance, classical Fenton reaction, heterogeneous Fenton-like reaction, processes which employ any of these physical fields such as electrical, microwave, ultraviolet and ultrasonic (Comninellis et al. 2008; John and Shaike 2015; Lahkimi et al. 2007; Paramo-Vargas et al. 2016; Rayaroth et al. 2016). Advanced oxidation processes involving physical fields have not been widely adopted by the industry yet for a reliable wastewater treatment due to high energy and capital cost. Therefore, in this article we will first briefly discus Fenton reaction and finally focus on heterogeneous Fenton-like reaction (Fig. 1) because the classical Fenton reaction which is currently in place for wastewater treatment lacks processing and economic sustainability.

\section{Homogeneous Fenton reaction}

The Fenton reaction was developed by Henry John Horstman Fenton in 1890 (Barbusiński 2009; Fenton 1894). The Fenton reagent comprising of ferrous ions and an oxidant $\mathrm{H}_{2} \mathrm{O}_{2}$ yields transitory but extremely reactive species, i.e., hydroxyl radicals, which have remarkable oxidizing capability (Goldstein et al. 1993; Jain et al. 2018; Navalon et al. 2011; Neyens and Baeyens 2003). Although the Fenton's reagent was discovered 100 years ago, it was not applied for

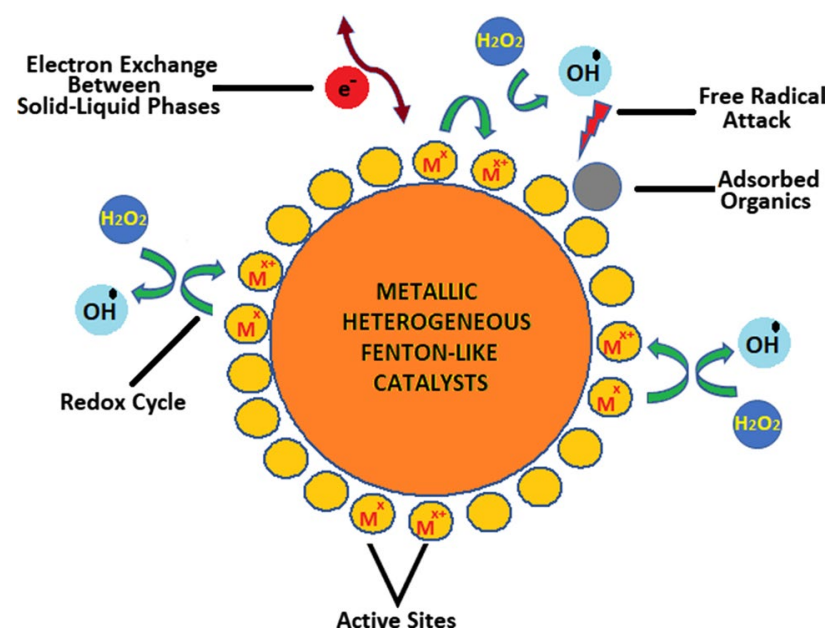

Fig. 1 Heterogeneous Fenton-like oxidation process the abatement of toxic organic pollutants until 1960 (Huang et al. 1993). It is critically important to comprehend the mechanism of Fenton reaction where ferrous (II) iron is mixed with $\mathrm{H}_{2} \mathrm{O}_{2}$, hydroxyl radicals are generated through the following chain initiation (Eq. 1) (Barhoumi et al. 2017) and chain termination (Eq. 2) reactions (Buxton et al. 1988; Rigg et al. 1954). The ferric (III) iron may also react with $\mathrm{H}_{2} \mathrm{O}_{2}$ and decompose it through the reaction outlined in (Eq. 3), and this particular reaction is referred as Fentonlike reaction (Walling and Goosen 1973). A series of other reactions involved in the Fenton process are outlined here (Eqs. 4-7) (Feng et al. 2013; Neyens and Baeyens 2003).

$$
\begin{aligned}
& \mathrm{Fe}^{+2}+\mathrm{H}_{2} \mathrm{O}_{2} \rightarrow \mathrm{Fe}^{+3}+\mathrm{OH}^{\cdot}+\mathrm{OH}^{-} \\
& \mathrm{Fe}^{+2}+\mathrm{OH} \rightarrow \mathrm{OH}^{-}+\mathrm{Fe}^{+3} \\
& \mathrm{Fe}^{+3}+\mathrm{H}_{2} \mathrm{O}_{2} \leftrightarrow \mathrm{Fe}-\mathrm{OOH}^{+2}+\mathrm{H}^{+} \\
& \mathrm{Fe}-\mathrm{OOH}^{+2} \rightarrow \mathrm{HO}_{2}^{\cdot}+\mathrm{Fe}^{+2} \\
& \mathrm{Fe}^{+2}+\mathrm{HO}_{2}^{\cdot} \rightarrow \mathrm{Fe}^{+3}+\mathrm{HO}_{2}^{-} \\
& \mathrm{Fe}^{+3}+\mathrm{HO}_{2}^{\cdot} \rightarrow \mathrm{Fe}^{+2}+\mathrm{O}_{2}+\mathrm{H}^{+} \\
& \mathrm{OH}^{\bullet}+\mathrm{H}_{2} \mathrm{O}_{2} \rightarrow \mathrm{H}_{2} \mathrm{O}+\mathrm{HO}_{2}^{\cdot}
\end{aligned}
$$

Instead of looking into all these complex reactions, Walling (Walling 1975) proposed a simplified version of Fenton reaction (Eq. 8) (Dhakshinamoorthy et al. 2012):

$\mathrm{Fe}^{+2}+\mathrm{H}_{2} \mathrm{O}_{2}+2 \mathrm{H}^{+} \rightarrow 2 \mathrm{Fe}^{+3}+2 \mathrm{H}_{2} \mathrm{O}_{2}$

The $\mathrm{OH}^{\bullet}$ reacts with organics and converts them into organic radicals which undergo a series of oxidation reactions to yield secondary and tertiary metabolites (Eq. 9) (Nidheesh 2015; Nidheesh et al. 2013):

$\mathrm{RH}+\mathrm{OH}^{\bullet} \rightarrow \mathrm{H}_{2} \mathrm{O}+\mathrm{R}^{\bullet} \rightarrow$ Oxidation

Homogeneous Fenton reaction essentially involves three processing steps: dissolution of the catalyst (de la Plata et al. 2010), $\mathrm{OH}^{\bullet}$ radical generation and finally the oxidation of organics (Fig. 2). Fenton reaction is mainly dependent on the extent of dissolution of iron catalyst, and this is the reason for which Fenton reaction does not afford good efficacy at near-neutral $\mathrm{pH}$ conditions. To improve the efficiency of the process, the $\mathrm{pH}$ of the aqueous medium has to be shifted toward acidic conditions which favors the dissolution of the catalyst. Almost all researchers have concluded that acidic conditions near $\mathrm{pH}-3$ afford the best efficiency for Fenton process (Aziz and Daud 2012; Bautista et al. 2008; Deng 
Fig. 2 Homogeneous Fenton process. Homogeneous Fenton reaction involves three processing steps: dissolution of the catalyst, $\mathrm{OH}^{*}$ radical generation and the oxidation of organics

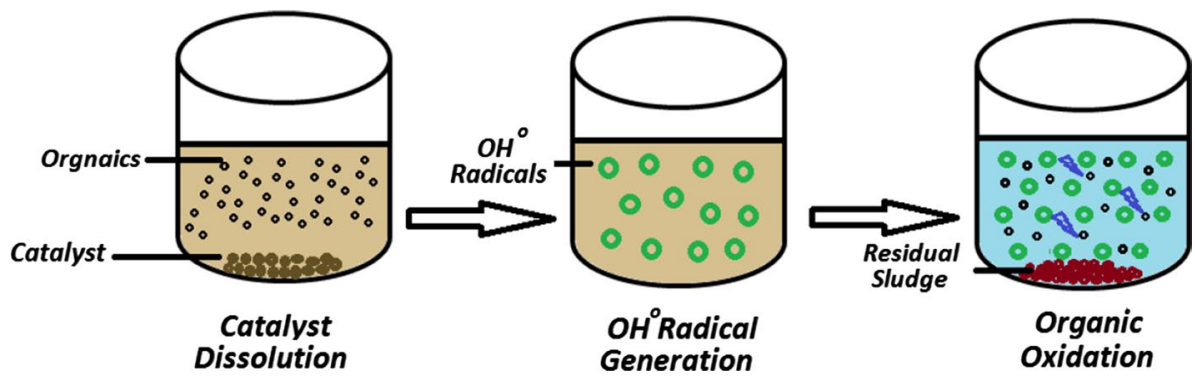

and Englehardt 2006; Lucas and Peres 2009; Umar et al. 2010). Apart from conducive $\mathrm{pH}$ conditions, there are several other factors which may influence the dissolution of the catalyst and can be explained using Noyes-Whitney equation (Eq. 10) (Noyes and Whitney 1897; Otsuka et al. 2007):

$\frac{d W}{d t}=\frac{D A(C s-C)}{L}$

where

$\frac{d W}{d t}$ is rate of catalyst dissolution

A is surface area of the catalyst, C is concentration of the solid catalyst in the bulk dissolution medium, Cs is concentration of the solid catalyst in the diffusion layer surrounding the solid, D is diffusion coefficient, $\mathrm{L}$ is diffusion layer thickness.

This equation clearly suggests that catalyst surface area plays a critical role and is proportional to the rate of dissolution of the catalyst. Further, larger quantities of catalyst also enhance the solubility of solid due to higher concentration gradient between liquid and solid phases. Moreover, the characteristics of dissolving medium, i.e., wastewater, also govern the solubility of catalyst. It is also important to note that the nature of the iron catalyst may also affect the dissolution rate.

Once the catalyst is dissolved, the $\mathrm{Fe}^{+2}$ ions start producing $\mathrm{OH}^{\bullet}$ radicals from the oxidant. The rate of $\mathrm{OH}^{\bullet}$ radicals mainly depends on the concentrations of both the catalyst and the oxidant. However, excess amounts of either of these entities beyond optimal conditions may also trigger a scavenging effect which may hinder the process efficiency (Eqs. 11 and 12) (Aşçı 2013; Nasuha et al. 2016):

$$
\begin{aligned}
& \mathrm{Fe}^{2+}+\mathrm{OH}^{\bullet} \rightarrow \mathrm{Fe}^{3+}+\mathrm{OH}^{-} \\
& \mathrm{H}_{2} \mathrm{O}_{2}+\mathrm{OH}^{\cdot} \rightarrow \mathrm{HO}_{2}^{\cdot}+\mathrm{H}_{2} \mathrm{O}
\end{aligned}
$$

Therefore, to avoid the adverse effects of scavenging phenomenon, Fenton process must be optimized with respect to catalyst and oxidant doses.

The transitory $\mathrm{OH}^{\bullet}$ radicals then attack on the organic molecules and abstract one of their hydrogen atoms and turn them into $\mathrm{R}^{\bullet}$ which ultimately undergoes a series of oxidation reactions to yield secondary and tertiary products, ideally $\mathrm{H}_{2} \mathrm{O}$ and $\mathrm{CO}_{2}$. Organics must go through the oxidation process, and consequently, the nature of the organics not only affects the extent of oxidation but also the quality of the finally treated wastewater. Therefore, hydrocarbons with stable and high molecular weights tend to yield relatively stable radicals which are difficult to oxidize. Another factor which hinders their oxidation is their poor solubility in the aqueous medium because homogeneous Fenton reaction must take place in the solution phase. The order of stability and consequently the difficulty posed by organic pollutants to undergo oxidation are illustrated in Fig. 3 (Perathoner and Centi 2005).

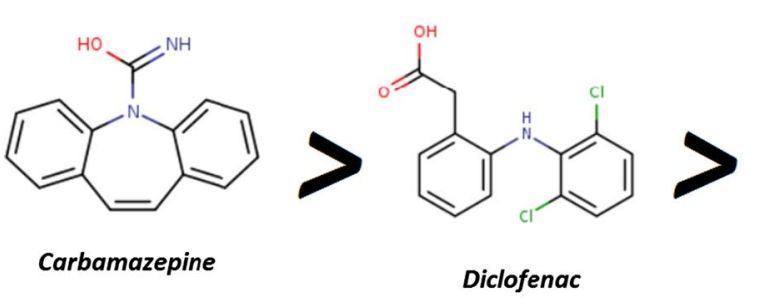

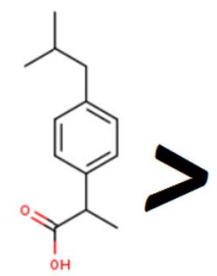

Ibuprofen

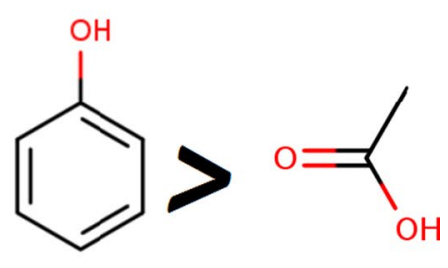

Phenol

Acetic acid

Fig. 3 Order of organic pollutants stability toward oxidation (most stable left) 


\section{Limitations of Fenton process}

Fenton process has many advantages such as processing of wastewater at ambient conditions, high reaction rate between $\mathrm{H}_{2} \mathrm{O}_{2}$ \& $\mathrm{Fe}$ (II) (Pouran et al. 2014), nontoxic reagents and convenience of integration with existing treatment facilities (Brillas et al. 2009). Moreover, Fenton process has been successfully employed for the treatment of numerous industrial wastewaters (Aziz and Daud 2012; Deng and Englehardt 2006; Lucas and Peres 2009; Mosteo et al. 2007; Soares et al. 2014; Wang et al. 2016). However, homogeneous Fenton reaction is only feasible when $\mathrm{pH}$ is lower than 4 because the interconversion of $\mathrm{Fe}^{+2}$ and $\mathrm{Fe}^{+3}$ maximizes the process efficiency (Tang et al. 2019). When $\mathrm{pH}$ exceeds $4, \mathrm{Fe}^{+3}$ is converted into ferric hydroxide sludge and part of the catalyst is lost and hence efficacy of the Fenton reaction declines (Garrido-Ramírez et al. 2010). The rigid acidic conditions require constant addition of chemicals before and after wastewater treatment and thus lead the process toward economic nonfeasibility. Besides, handling and disposal of solid sludge incur additional costs. Moreover, the newly formed sludge may also serve as an absorbent for the pollutants in the wastewater and hence give rise to another environmental hazard. Furthermore, recycling of the iron sludge is also not feasible.

\section{Heterogeneous Fenton-like reaction}

Fenton-like reaction is established when $\mathrm{Fe}^{+2}$ is either replaced with $\mathrm{Fe}^{+3}$ or other transition metal ions in the Fenton reagent system (Wang et al. 2016). Although heterogeneous Fenton-like reaction also coexists within homogeneous Fenton reaction, it is limited because of the narrow $\mathrm{pH}$ range and quickly dissipates once favorable conditions are inverted (Caudo et al. 2006). Heterogeneous Fenton-like reaction can be successfully used to overcome the processing and economic constraints associated with homogeneous Fenton reaction such as high input of chemicals, catalyst loss and large amount of sludge generation (Centi et al. 2000; Navalon et al. 2010). In heterogeneous Fenton reaction, the $\mathrm{Fe}^{+3}$ is principally used in the nonsoluble form either harnessing naturally occurring minerals such as magnetite $\left(\mathrm{Fe}_{3} \mathrm{O}_{4}\right)$, maghemite $\left(\gamma-\mathrm{Fe}_{2} \mathrm{O}_{3}\right)$, hematite $\left(\alpha-\mathrm{Fe}_{2} \mathrm{O}_{3}\right)$ and pyrite $\left(\mathrm{FeS}_{2}\right)$ (Feng et al. 2012; Pereira et al. 2012) or impregnating it over suitable supports to afford extended surface area (Flores et al. 2008; Gumy et al. 2005; Muthuvel and Swaminathan 2008; Xue et al. 2009).

Heterogeneous Fenton process is altogether different when compared with homogeneous Fenton process because adsorption is mainly responsible for determining the efficiency of the process. There are three steps involved in heterogeneous Fenton process: adsorption of organics over the catalyst surface, in situ generation and attack of $\mathrm{OH}^{\bullet}$ radicals on organics (He et al. 2016) and finally desorption of oxidation products from catalyst surface (Fig. 4). In order to explain the driving force of adsorption in heterogeneous Fenton oxidation, Langmuir equation can be used (Eq. 13):

$\frac{C e}{Q e}=\frac{1}{Q m K l}+\frac{C e}{Q m}$

where $C_{e}$ is equilibrium concentration of organics, $Q_{e}$ is equilibrium monolayer adsorption capacity, $\mathrm{Q}_{\mathrm{m}}$ is complete monolayer adsorption capacity, $\mathrm{K}_{1}$ is Langmuir adsorption constant.

The equation clearly suggests that the rate of adsorption predominantly depends upon the monolayer adsorption capacity of the solid catalyst. This further suggests that higher surface area of the catalyst is exposed in the aqueous medium, resulting in a higher organic adsorption (Geçgel et al. 2015). Although multilayer adsorption may also exist, it only happens when organics are present in very high concentrations. Once the organics are adsorbed onto catalyst surface, $\mathrm{OH}^{\bullet}$ radicals are generated through active sites on the catalyst surface and start oxidizing the organics. The oxidation products either undergo further oxidation or desorb from the catalysts surface, completing the heterogeneous catalytic cycle.

Originally, heterogeneous Fenton process was developed by harnessing iron $\left(\mathrm{Fe}^{+3}\right)$ to overcome the disadvantages of homogeneous Fenton process, mitigating several processing constraints such as reduced sludge generation, lower

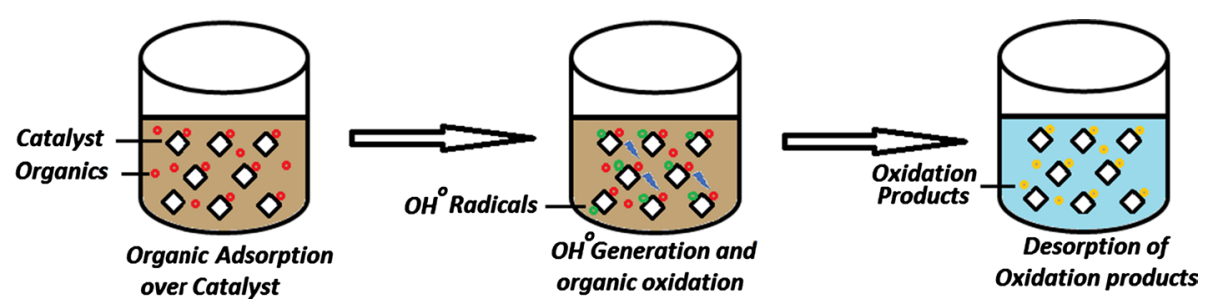

Fig. 4 Heterogeneous Fenton process. Heterogeneous Fenton reaction essentially involves three processing steps: adsorption of organics over the catalyst surface, $\mathrm{OH}^{\bullet}$ radicals generation through active sites on the catalyst surface and oxidation of the organics, desorption of the oxidation products from the catalysts surface 
chemical input and hence lower cost. However, $\mathrm{pH}$ optimization and control remain the major defect in the process because in order to afford high efficiency, acidic conditions are favorable but in doing so metal ions start coming off from the catalyst surface. Leaching of the active metal from the catalyst surface inevitably results in lowering the catalytic activity, turning the process less sustainable. Therefore, many researchers have been striving to employ various metals including iron to develop heterogeneous catalysts with enhanced stability without compromising the acceptable activity threshold. Now, we will discuss frequently used metals for the development of heterogeneous catalyst for Fenton oxidation and critically analyze their performance in terms of activity and stability. Specifically, we will focus on iron, cerium, copper, manganese and silver catalysts.

Iron-based catalysts have been mainly discussed because the main idea of the Fenton and Fenton-like processes originated using iron-containing materials. This is the only metal which forms stable complexes with the degradation products.

Copper-based materials have been considered due to the redox cycle that is very similar to that of iron. Moreover, unlike iron, copper forms temporary complexes with the degradation products.

Silver has been chosen because of its unique redox cycle involving elemental $\mathrm{Ag}$ and $\mathrm{Ag}^{+}$.

Cerium has been taken into consideration because this is the only metal when employed in Fenton-like oxidation process forms complexes with the oxidant.

Manganese has been included in the review because it offers two separate redox cycles depending upon the nature of manganese-based material.

\section{Role of metals in heterogeneous Fenton-like oxidation}

\section{Considerations for development of sustainable catalyst}

The fundamental prerequisites to develop a sustainable heterogeneous catalyst for Fenton oxidation are high activity and stability. In order to achieve these features in a catalyst, it is essential that the metal used for catalyst development can exist in multiple oxidation states due to its higher capacity to transform $\mathrm{H}_{2} \mathrm{O}_{2}$ into $\mathrm{OH}^{\bullet}$ radicals (Bokare and Choi 2014). Moreover, all these oxidation states ought to be stable over a wide range of $\mathrm{pH}$ to avoid the loss of catalyst though leaching. Another aspect which must be considered is the resistance of the metallic species toward hydration forces/ nonsoluble nature of the metallic ions. Apart from these requirements, the metal entities must have the potential to transform pollutants into terminal oxidation products, i.e., $\mathrm{CO}_{2}$ and $\mathrm{H}_{2} \mathrm{O}$.

\section{Iron}

The abundant and cost-effective availability of iron is the prime reason due to which researchers are still focused to develop heterogeneous catalysts by employing this metal (Pereira et al. 2012). Another reason for harnessing this metal is its high activity in Fenton process and familiarity with reaction mechanism (Pouran et al. 2014). Iron-based heterogeneous catalysts are still the most widely used catalysts in Fenton-like process, and many researchers have reported their findings which are presented in Table 1. Iron can exhibit its heterogeneous catalytic features cycling between $\mathrm{Fe}^{3+}$ and $\mathrm{Fe}^{2+}$ (Feng et al. 2013; Hartmann et al. 2010; Rusevova et al. 2012); some researchers have also proposed high-valent iron species such as ferryl $\left(\mathrm{Fe}^{+4}\right)$ but these species only exist in basic conditions (Gonzalez-Olmos et al. 2011; He et al. 2016; Luo et al. 2010).

\section{Controlling parameters}

The nature of the iron-based catalyst is the governing parameter which dictates rest of the factors for optimal performance of the catalyst in Fenton process because coordination of the iron species in different catalytic environments is inherently different; the nature of the catalyst predominantly regulates the optimization of the parameters in Fenton process (Wang et al. 2013). For example, there is a marked difference of optimal $\mathrm{pH}$ between $\mathrm{BiFeO}_{3}$ and zerovalent iron (Table 1). Likewise, similar iron-based catalysts such as nanoparticle iron and zerovalent iron yield maximum activity at identical $\mathrm{pH}$ conditions.

The parameters $\mathrm{pH}$, catalyst dose, oxidant dose, temperature, reaction time and pollutant type will strongly affect the efficiency of the Fenton process. The most critical parameter for iron-based heterogeneous catalysis is the $\mathrm{pH}$ of the wastewater. Acidic $\mathrm{pH}$ conditions yield higher activity of the process because part of the iron species is lost into the solution phase and may contribute toward improving efficiency of the process through partial homogeneous Fenton reaction (Rusevova et al. 2014). However, this will also cause substantial metal loss from catalyst surface and turn the catalyst less active in subsequent cycles. Moreover, acidic $\mathrm{pH}$ conditions of the aqueous solutions are adjusted by the addition of $\mathrm{HCl}$ or $\mathrm{H}_{2} \mathrm{SO}_{4}$ and this will increase the concentration of $\mathrm{SO}_{4}{ }^{2-}$ and $\mathrm{Cl}^{-}$ions, which are known as inhibitors for the generation of $\mathrm{OH}^{\bullet}$ radicals, thus adversely affecting the overall process efficacy (Lin et al. 2015).

Another important parameters are the catalyst dose and the associated surface area of the catalyst. Generally, higher catalyst loadings favor the efficacy of the Fenton process, 
Table 1 Iron-based heterogeneous catalysts

\begin{tabular}{|c|c|c|c|c|c|c|c|c|}
\hline Catalyst composition & $\begin{array}{l}\text { Catalyst } \\
\text { dose } \\
(\mathrm{g} / \mathrm{l})\end{array}$ & $\begin{array}{l}\mathrm{H}_{2} \mathrm{O}_{2} \\
\text { dose } \\
(\mathrm{mM} / \mathrm{l})\end{array}$ & $\mathrm{pH}$ & $\mathrm{T}\left({ }^{\circ} \mathrm{C}\right)$ (time) & Target compound & Degradation (\%) & $\begin{array}{l}\text { Miner- } \\
\text { alization } \\
(\%)\end{array}$ & References \\
\hline Fe(III)AspSiW & 0.2 & 20 & 6.5 & $25(30 \mathrm{~min})$ & 4-chlorophenol & 100 & 85 & (Chen et al. 2015a) \\
\hline $\mathrm{Fe}_{3} \mathrm{O}_{4}$ Nanoparticle & 0.1 & 1 & 3 & $25(30 \mathrm{~min})$ & Methylene blue & 100 & 77 & (Wei et al. 2020) \\
\hline $\mathrm{Fe}_{0} / \mathrm{Fe}_{3} \mathrm{O}_{4}$ & 3 & 300 & 6 & $25(2 \mathrm{~h})$ & Methylene blue & 100 & 75 & (Costa et al. 2008) \\
\hline $\begin{array}{l}\text { Iron over activated } \\
\text { carbon }\end{array}$ & 0.1 & 6 & 3 & $30(24 \mathrm{~h})$ & Azo dye orange II & 100 & 60 & (Duarte et al. 2012) \\
\hline Fe-Lap-RD & 1 & 60 & 3 & $25(30 \mathrm{~min})$ & Ciprofloxacin & 100 & 57 & (Bobu et al. 2008) \\
\hline Zerovalent iron & 1 & 128 & 3 & 20 (8 min) & 4-chlorophenol & 100 & - & (Zhou et al. 2008) \\
\hline $\mathrm{Fe}_{3} \mathrm{O}_{4} / \gamma \mathrm{Al}_{2} \mathrm{O}_{3}$ & 1 & 44 & 3 & $\begin{array}{l}50(3 \mathrm{~h}) \\
50(2 \mathrm{~h}) \\
50(1 \mathrm{~h})\end{array}$ & $\begin{array}{l}\text { 4-chlorophenol } \\
\text { 2,4-dichlorophenol } \\
\text { 2,4,6-trichlorophenol }\end{array}$ & $\begin{array}{l}100 \\
100 \\
100\end{array}$ & - & (Munoz et al. 2013) \\
\hline $\mathrm{GO} / \mathrm{Fe}_{3} \mathrm{O}_{4}$ & 0.2 & 22 & 3 & $25(3 \mathrm{~h})$ & Acid Orange 7 & 100 & - & (Zubir et al. 2014) \\
\hline $\mathrm{Fe}_{3} \mathrm{O}_{4} / \mathrm{CeO}_{2}$ & 2 & 30 & 3 & $30(2 \mathrm{~h})$ & 4-Chlorophenol & 100 & - & (Xu and Wang 2012) \\
\hline $\mathrm{FeNi} / \mathrm{C}-300$ & 1 & 100 & 7 & $25(1 \mathrm{~h})$ & Methylene blue & 100 & - & (Li et al. 2020) \\
\hline Fe/saponite clay & 0.07 & 13 & 3 & $40(4 \mathrm{~h})$ & Azo dye & 100 & - & $\begin{array}{l}\text { (Herney-Ramirez et al. } \\
\text { 2008) }\end{array}$ \\
\hline Fe/clinoptilolite & 5 & 3 & 3 & $25(1 \mathrm{~h})$ & Phenol & 100 & - & (Bayat et al. 2012) \\
\hline Quartz/goethite & 0.1 & 58 & 5 & $20(30 \mathrm{~min})$ & Methyl red & 100 & - & (Hanna et al. 2008) \\
\hline Fe/Faujasite Y zeolite & 1 & 7 & 5.5 & $20(4 \mathrm{~h})$ & Phenol & 100 & - & (Ayoub et al. 2018) \\
\hline Nanoparticle iron & 0.5 & 3.0 & 3 & $30(1 \mathrm{~h})$ & $\begin{array}{l}\text { 4-Chloro-3-methyl } \\
\text { phenol }\end{array}$ & 99 & 63 & (Xu and Wang 2011) \\
\hline $\mathrm{Fe}_{2} \mathrm{O}_{3}$ & 20 & 24 & 2.5 & $25(2 \mathrm{~h})$ & Drimarene & 99 & - & (Araujo et al. 2011) \\
\hline Fe-Zeolite Y & 2.5 & 16 & 2.5 & $30(1 \mathrm{~h})$ & Acid red I & 99 & - & $\begin{array}{l}\text { (Hassan and Hameed } \\
\text { 2011b) }\end{array}$ \\
\hline Fe Clay & 5 & 8 & 3 & $30(3 \mathrm{~h})$ & Reactive blue 4 & 99 & - & $\begin{array}{l}\text { (Hassan and Hameed } \\
\text { 2011a) }\end{array}$ \\
\hline Amorphous FeOOH & 2.5 & 15.8 & 7 & $1.5 \mathrm{~h}$ & Methyl orange & 99 & - & (Li and Zhang 2010) \\
\hline Fe-Al Clay & 0.3 & 4 & 4 & $30(3 \mathrm{~h})$ & Phenol & 99 & - & (Luo et al. 2009) \\
\hline $\mathrm{Fe}_{0}-\mathrm{Fe}_{3} \mathrm{O}_{4}-\mathrm{RGO}$ & 0.1 & 0.8 & 3 & $25(1 \mathrm{~h})$ & Methylene Blue & 98 & - & (Yang et al. 2015) \\
\hline $\mathrm{AC}-\mathrm{FeOOH}$ & 1 & 10 & 7 & $30(4 \mathrm{~h})$ & Azo dye & 98 & - & (Wu et al. 2013) \\
\hline Fe/ZSM-5 & 1 & 267 & 3.5 & $60(2 \mathrm{~h})$ & Reactive red & 97 & - & (Yaman et al. 2013) \\
\hline Fedpa $/ \mathrm{SiO}_{2}$ & 0.87 & 4.5 & 8 & $25(2 \mathrm{~h})$ & 2,4-dichlorophenol & 95 & - & (Jin et al. 2020) \\
\hline $\mathrm{FeVO}_{4}$ & 0.5 & 15 & 6.1 & $25(1 \mathrm{~h})$ & Methyl orange II & 94.7 & - & (Deng et al. 2008) \\
\hline $\mathrm{Fe}_{2} \mathrm{O}_{3}$ Over $\mathrm{CeO}_{2}$ & 1 & 640 & 9.6 & $27(7 \mathrm{~h})$ & Methylene blue & 94 & - & $\begin{array}{l}\text { (Divya and Renuka } \\
\text { 2015) }\end{array}$ \\
\hline $\mathrm{Fe}_{2} \mathrm{O}_{3}$-MWCNTs & 0.5 & 15 & 3.5 & $25(30 \mathrm{~min})$ & Acid orange II & 94 & - & (Deng et al. 2012) \\
\hline $\mathrm{Fe}_{2}\left(\mathrm{MoO}_{4}\right)_{3}$ & 1.4 & 18 & 3 & $30(1 \mathrm{~h})$ & Acid orange II & 94 & - & (Tian et al. 2011) \\
\hline $\mathrm{Fe}^{\mathrm{II}} @ \mathrm{MIL}-100(\mathrm{Fe})$ & 1 & 40 & 3 & $25(5 \mathrm{~h})$ & Methylene blue & 91 & - & (Lv et al. 2015) \\
\hline $\mathrm{LaFeO}_{3}$ and $\mathrm{BiFeO}_{3}$ & 0.1 & 26 & 5 & 40 & Phenol & 90 & - & (Rusevova et al. 2014) \\
\hline NZVI/CD particles & 1 & 60 & 3.5 & $25(1 \mathrm{~h})$ & Amoxicillin & 90 & - & (Pirsaheb et al. 2019) \\
\hline SCFA & 10 & 5 & 3 & $30(1.5 \mathrm{~h})$ & p-nitrophenol & 90 & - & (Wang et al. 2018) \\
\hline $\mathrm{FeS}$ & 0.5 & 10 & 4.5 & $50(5 \mathrm{~h})$ & $\begin{array}{l}\text { 2,4-Dichlorophenoxy- } \\
\text { acetic acid }\end{array}$ & 88 & - & (Chen et al. 2015b) \\
\hline Zero valent iron & 0.5 & 6.6 & 3 & $30(20 \min )$ & Amoxicillin & 86.5 & - & (Zha et al. 2014) \\
\hline Fe/ZSM-5 & 0.2 & 8.35 & 4 & $60(2 \mathrm{~h})$ & Acetic acid & - & 50.5 & (Cihanoğlu et al. 2015) \\
\hline
\end{tabular}

especially when iron-based heterogeneous catalysts are used, but beyond a certain point it may also negatively impact the efficacy due to scavenging effect, i.e., consumption of $\mathrm{OH}^{\bullet}$ radicals by the catalyst itself (Chen et al. 2015b; Divya and Renuka 2015). Heterogeneous Fenton process is a surface phenomenon and higher surface area of the catalyst will increase the effectiveness of the catalyst. However, extended surface area of iron-based catalysts may subject 
them to strong hydration forces, especially in acidic conditions, and ultimately result in the increase in metal loss (Duarte et al. 2012).

Obviously, oxidant dose is also critical when it comes to achieve optimal efficiency in Fenton process. However, it has been observed that when iron-based catalysts are used, only a small excess of oxidant is required to obtain maximum pollutant abatement (Chen et al. 2015b; Duarte et al. 2012). It is also worth mentioning that the type of the pollutants will regulate not only the extent of oxidation but also the degree to which oxidation objectives are achieved, i.e., whether a mere degradation of the organics is required, or a complete mineralization is the primary objective.

A key characteristic of the Fenton-like process carried out by iron-based catalysts is their ability to degrade wide range of organics (Zhou et al. 2008). Further, iron-based catalysts afford high reaction rates in terms of organic degradation, but rate of mineralization is far slower due to two possible reasons. First, the oxidation products do not desorb from catalyst surface; second, due to their inability to generate in situ $\mathrm{R}^{\bullet}$ radicals from secondary oxidation products because $\mathrm{Fe}^{+3}$ forms very stable complexes with oxidation products and ultimately inhibits the oxidation of degraded products as shown in Fig. 5 (Salazar et al. 2012; Sirés et al. 2006; Vindedahl et al. 2016).

\section{Copper}

Copper is the second most used transition metal in heterogeneous Fenton process because of several characteristics such as inexpensiveness, abundant availability, nontoxic nature and high activity. Another feature which has attracted the attention of research community is its similar redox behavior like iron. There are two oxidation states of copper, i.e., cuprous $\left(\mathrm{Cu}^{+}\right)$and cupric $\left(\mathrm{Cu}^{+2}\right)$, which can react with $\mathrm{H}_{2} \mathrm{O}_{2}$ to form $\mathrm{OH}^{\bullet}$ radicals (Bokare and Choi 2014). However, copper has a distinct property which makes it even a better catalytic entity when compared with iron, its ability to form temporary complexes with oxidation products and rapid interconversion of $\mathrm{Cu}^{+}$into $\mathrm{Cu}^{+2}$ and vice versa (Lyu et al. 2015). The oxidation products do not form permanent complexes with copper, and hence the active sites remain available for continuous catalytic cycle (Fig. 6). Therefore, copper not only offers better redox cycle, but is also active in the mineralization of organics. Several researchers have employed copper in variable forms as heterogeneous catalyst in Fenton process (Table 2).

\section{Controlling parameters}

The principal feature of copper-based heterogeneous catalysts is their potential to perform well over a broad $\mathrm{pH}$ range, especially at near-neutral $\mathrm{pH}$ conditions. However, the optimal $\mathrm{pH}$ conditions depend upon the nature of the catalyst and its corresponding value of point of zero charge. Unlike

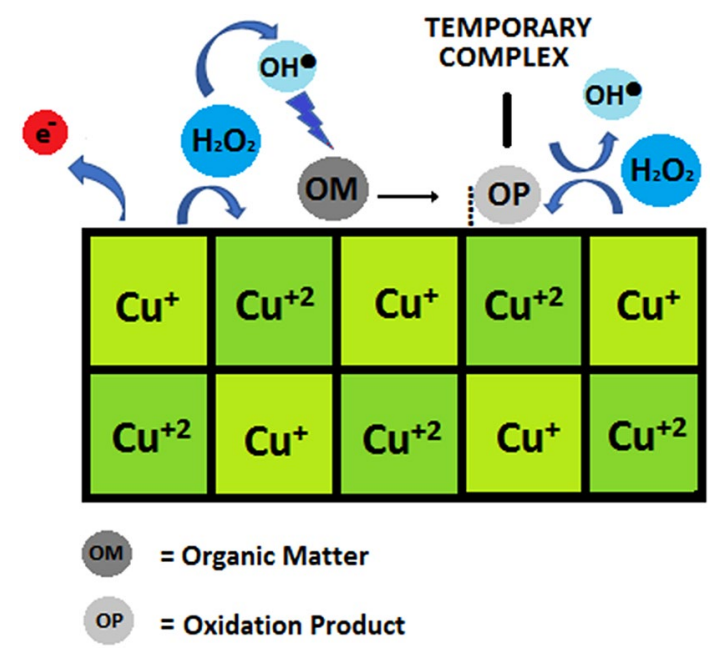

Fig. 6 Complex formation of copper with oxidation products. The oxidation products do not form permanent complexes with copper, and hence the active sites remain available for continuous catalytic cycle
Fig. 5 Complex formation of iron with oxidation products. The organics are adsorbed over the catalyst surface where they are oxidized by the iron-based catalyst. After the oxidation, the formation of very stable complexes between $\mathrm{Fe}^{3+}$ and oxidation products inhibits the desorption of the reaction products

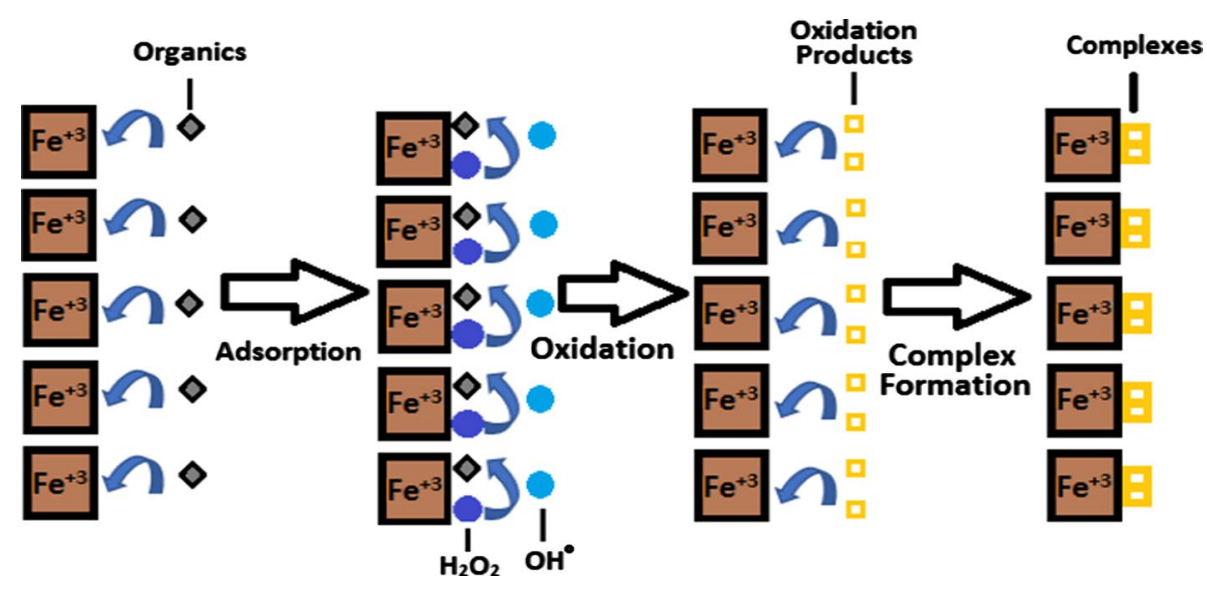


Table 2 Copper-based heterogeneous catalysts

\begin{tabular}{|c|c|c|c|c|c|c|c|c|}
\hline $\begin{array}{l}\text { Catalyst composi- } \\
\text { tion }\end{array}$ & Catalyst dose $(\mathrm{g} / \mathrm{l})$ & $\begin{array}{l}\mathrm{H}_{2} \mathrm{O}_{2} \\
\text { dose } \\
(\mathrm{mM} / \mathrm{l})\end{array}$ & $\mathrm{pH}$ & $\mathrm{T}\left({ }^{\circ} \mathrm{C}\right)$ (time) & Target compound & Degradation (\%) & $\begin{array}{l}\text { Miner- } \\
\text { alization } \\
(\%)\end{array}$ & References \\
\hline $5 \mathrm{Cu} / \mathrm{ZrO}_{2}$ & 0.25 & 32 & 5 & $70(2 \mathrm{~h})$ & Ibuprofen & 100 & 53 & (Hussain et al. 2020) \\
\hline CuFe/ZSM-5 & 0.15 & 40 & 3.5 & $50(2 \mathrm{~h})$ & Rhodamine $6 \mathrm{G}$ & 100 & 51.8 & $\begin{array}{l}\text { (Dükkanc1 et al. } \\
\text { 2010) }\end{array}$ \\
\hline Copper slag & 2.49 & 4.7 & 3 & $30(4 \mathrm{~h})$ & Phenol & 100 & 50 & $\begin{array}{l}\text { (Huanosta-Gutiérrez } \\
\text { et al. 2012) }\end{array}$ \\
\hline $\mathrm{CuFe}_{2} \mathrm{O}_{4} / \mathrm{rGO}$ & 0.6 & 660 & 7 & $25(4 \mathrm{~h})$ & Phenol & 100 & - & (Othman et al. 2019) \\
\hline $\begin{array}{l}\text { Copper-doped } \\
\text { mesoporous } \\
\text { silica }\end{array}$ & 0.4 & 10 & 5 & $30(2 \mathrm{~h})$ & Ibuprofen & 100 & - & (Lyu et al. 2015) \\
\hline $\mathrm{Cu} / \mathrm{SiO}_{2}$ & $0.035 \mathrm{Cu}$ & 29 & - & $60(1 \mathrm{~h})$ & Rhodamine B & 100 & - & (Sun et al. 2019) \\
\hline $\begin{array}{l}\mathrm{Cu}(\mathrm{I}) \text {-doped nano- } \\
\mathrm{Fe}_{3} \mathrm{O}_{4}\end{array}$ & 0.1 & 10 & 6 & $25(2 \mathrm{~h})$ & Carbamazepine & 100 & - & (Yang et al. 2019) \\
\hline $\mathrm{Cu}-\mathrm{Fe}_{3} \mathrm{O}_{4} @ \mathrm{SiO}_{2}$ & $1(0.2 \mathrm{cu}-\mathrm{fe})$ & 15 & 5 & $25(2 \mathrm{~h})$ & Acetaminophen & 100 & - & (Do et al. 2018) \\
\hline $\begin{array}{l}\mathrm{CuFeO}_{2} \text { Micropar- } \\
\text { ticles }\end{array}$ & 1 & 20 & 5 & $30(2 \mathrm{~h})$ & Bisphenol & 99.2 & 85 & (Zhang et al. 2014) \\
\hline $\mathrm{CuO}$ over $\mathrm{CeO}_{2}$ & 1 & 640 & 9.6 & 27 (7 h) & Methylene blue & 99 & - & $\begin{array}{l}\text { (Divya and Renuka } \\
\text { 2015) }\end{array}$ \\
\hline $\begin{array}{l}\text { Cobalt-copper } \\
\text { oxalate nanofib- } \\
\text { ers }\end{array}$ & 0.1 & 380 & 5 & $30(5 \mathrm{~h})$ & Congo Red & 99 & - & (Shen et al. 2017) \\
\hline $\mathrm{Cu}-\mathrm{CuFe}_{2} \mathrm{O}_{4} / \mathrm{SiO}_{2}$ & 0.2 & 250 & 7 & 25 (2 h) & Methylene blue & 98 & - & (Wu et al. 2020) \\
\hline $\begin{array}{l}\mathrm{CuO} / \mathrm{SiO}_{2} \text { hollow } \\
\text { sphere }\end{array}$ & 6 & 34 & 3.5 & $60(2 \mathrm{~h})$ & acid scarlet $3 R$ & 97 & - & (Xie et al. 2015) \\
\hline $\mathrm{Co}_{0.5}-\mathrm{Cu}_{0.5} \mathrm{O}$ & 0.1 & 380 & 9 & $30(5 \mathrm{~h})$ & Congo red & 95 & - & (Shen et al. 2015) \\
\hline $7.5 \mathrm{CuY}$ & 1 & 200 & 5 & $60(4 \mathrm{~h})$ & Congo red & 93.58 & 79.52 & (Singh et al. 2016) \\
\hline CuFe-MC-1-800 & 0.3 & 30 & 3 & $25(1 \mathrm{~h})$ & $\begin{array}{l}\text { Bisphenol } \\
\text { Imidacloprid } \\
\text { Methylene Blue } \\
\text { 2,4,6-trichloro- } \\
\text { phenol } \\
\text { Methyl orange } \\
\text { Phenol } \\
\text { Benzoic acid } \\
\text { Ketoprofen }\end{array}$ & 93 & $\begin{array}{l}66.3 \\
94.3 \\
95.4 \\
93.5 \\
\\
\\
\\
86.9 \\
83.7 \\
81.4 \\
77.8\end{array}$ & (Wang et al. 2015) \\
\hline $\begin{array}{l}\text { Mesoporous Cu/ } \\
\text { TUD-1 }\end{array}$ & 0.1 & 90 & 3.5 & $25(3 \mathrm{~h})$ & Bisphenol & 90.4 & - & $\begin{array}{l}\text { (Pachamuthu et al. } \\
\text { 2017) }\end{array}$ \\
\hline $\begin{array}{l}\mathrm{Cu}^{2+} / \mathrm{Al}_{2} \mathrm{O}_{3}, \mathrm{Cu}^{2+} / \\
\mathrm{ZrO}_{2}\end{array}$ & 1 & 300 & 6.8 & $30(5 \mathrm{~h})$ & Bromophenol blue & 90 & - & (Salem 2000) \\
\hline $\mathrm{CuO}$ nanoparticles & 0.1 & 800 & 6 & $25(4 \mathrm{~h})$ & Enrofloxacin & 90 & - & (Fink et al. 2012) \\
\hline $\mathrm{CuO} / \mathrm{Al}_{2} \mathrm{O}_{3}$ & 0.2 & 40 & 5.5 & $21(2 \mathrm{~h})$ & Reactive black 5 & 90 & - & (Bradu et al. 2010) \\
\hline $\mathrm{Fe}-\mathrm{Cu} / \mathrm{Al}_{2} \mathrm{O}_{3}$ & 1.5 & 49 & 4 & $40(2 \mathrm{~h})$ & Phenol & - & 80 & (Xia et al. 2011) \\
\hline
\end{tabular}

iron catalysts, acidic conditions not only reduce the overall activity of these materials but also amplify the loss of metal from catalyst surface. Moreover, copper-based catalysts do not offer catalytic activity through homogeneous phase. Another advantage of copper over iron is its ability to afford better catalytic activities with lower catalyst dose because it possesses superior redox cycle and extended catalyst stability. Further, heterogeneous catalysis carried out by copper made catalysts is much faster. However, optimal catalyst dose ought to be determined experimentally and any additional amount of catalyst will bear strong scavenging effects and ultimately process efficiency will decline.

Copper-based catalysts have a serious disadvantage concerning oxidant dose: a fairly large excess of oxidant is required to obtain optimal pollutant abatement because molecular oxygen disturbs the redox cycle of copper and part of the oxidant is lost in the process. The large excess of $\mathrm{H}_{2} \mathrm{O}_{2}$ not only increases the cost of the Fenton process but 
also makes it susceptible to severe scavenging effect caused by the oxidant itself for $\mathrm{OH}^{\bullet}$ radicals (Bali and Karagözoğlu 2007; Miles and Brezonik 1981).

Contrary to iron, the activity of the copper-based catalysts is greatly influenced by variations in the reaction temperature. Higher reaction temperature favors the rate as well as efficiency of the Fenton process because the energy required by the organics and $\mathrm{H}_{2} \mathrm{O}_{2}$ to form oxidation products is supplied through an elevation in temperature (Konstantinou and Albanis 2004; Nasuha et al. 2016). However, beyond a certain point, temperature may also negatively impact the process efficiency due to the formation of undesirable stable oxidation products, loss of active sites through hydration forces and decomposition of oxidant into useless species.

$\mathrm{Cu}$-based catalysts have a main disadvantage which is the high excess of $\mathrm{H}_{2} \mathrm{O}_{2}$ requirement for maintaining the catalytic activity. This disadvantage has often been mitigated by employing a bimetallic composite of copper with iron and other transition metals. However, iron has been used more frequently and various studies have shown promising results in this regard. The induction of two metals not only enhances the catalytic activity but also increases the stability of the catalytic composite because of superior redox cycle

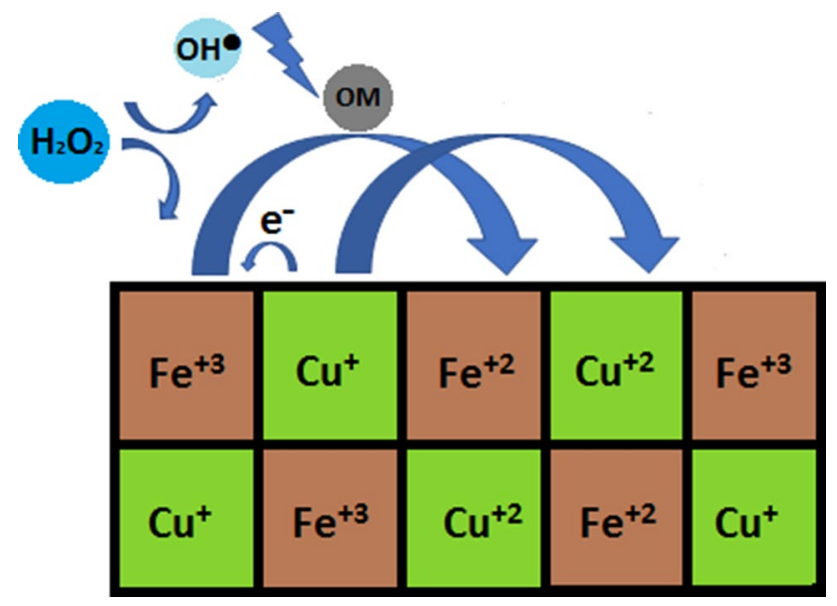

Fig. 7 Redox cycle of copper and iron bimetallic composite. $\mathrm{Fe}^{3+}$ is reduced to $\mathrm{Fe}^{2+}$, while $\mathrm{Cu}^{+}$is oxidized to $\mathrm{Cu}^{2+}$, favoring the oxidation of organics
(Fig. 7). Tian et.al. have summarized the redox mechanism of bimetallic redox cycle using a single equation (Eq. 14) (Tian et al. 2017):

$\mathrm{Fe}^{3+}+\mathrm{Cu}^{+} \rightarrow \mathrm{Fe}^{2+}+\mathrm{Cu}^{2+}$

$\mathrm{Fe}^{3+}$ is reduced to $\mathrm{Fe}^{2+}$ while $\mathrm{Cu}^{+}$is oxidized to $\mathrm{Cu}^{2+}$, favoring the oxidation of organic matter.

\section{Silver}

The main drive to use silver as a catalyst in Fenton-like process is its proven ability to oxidize organics such as methanol (Kundakovic and Flytzani-Stephanopoulos 1999), ethylene (Mao and Vannice 1995), methane and volatile organic compounds (Qu et al. 2005). He et.al. reported the use of silver nanoparticles for the generation of $\mathrm{OH}^{\bullet}$ from $\mathrm{H}_{2} \mathrm{O}_{2}$ (He et al. 2012). Until now, silver has not been widely studied as a heterogeneous Fenton catalyst (Table 3).

\section{Controlling parameters}

In the context of Fenton-like oxidation, silver can exist in two oxidation forms, i.e., $\mathrm{Ag}^{0}$ and $\mathrm{Ag}^{+1}$, depending upon the $\mathrm{pH}$ conditions of the aqueous medium; therefore, $\mathrm{pH}$ is the most crucial parameter (Saeed et al. 2018). Under acidic conditions, bare silver will tend to dissolve in the water phase and will transform $\mathrm{H}_{2} \mathrm{O}_{2}$ into $\mathrm{OH}^{\bullet}$ radicals through homogeneous phase. However, basic conditions will shift the redox reaction in the opposite direction and instead of $\mathrm{OH}^{*}$ radical generation, $\mathrm{O}_{2}$ is produced through heterogeneous phase reaction (Fig. 7). Keeping in view of these facts, silver can efficiently be used as heterogeneous catalyst when $\mathrm{pH}$ conditions are either neutral or basic. However, the unfavorable redox reactions will suppress the catalytic activity while the conditions become basic as suggested by Weaver and Frederikse (Eq. 15, and 16) (Weaver and Frederikse 1977). Additionally, basic conditions may activate the agglomeration of the catalyst particles, reducing surface area and diminishing the activity (Park et al. 2017). Moreover, with the progress of Fenton reaction, the degradation products

Table 3 Silver-based heterogeneous catalysts used in Fenton-like processes

\begin{tabular}{lllllllll}
\hline Catalyst composition & $\begin{array}{l}\text { Catalyst } \\
\text { dose }(\mathrm{g} / \mathrm{l})\end{array}$ & $\begin{array}{l}\mathrm{H}_{2} \mathrm{O}_{2} \\
\text { dose } \\
(\mathrm{mM} / \mathrm{l})\end{array}$ & $\mathrm{pH}$ & $\mathrm{T}\left({ }^{\circ} \mathrm{C}\right)(\mathrm{time})$ & Target compound & $\begin{array}{l}\text { Degra- } \\
\text { dation } \\
(\%)\end{array}$ & $\begin{array}{l}\text { Miner- } \\
\text { alization } \\
(\%)\end{array}$ & References \\
\hline $\mathrm{NZVI-Ag}$ & 0.025 & 5.3 & 3 & $25(1.5 \mathrm{~h})$ & 4-Cholorophenol & 100 & 80 & $\begin{array}{l}\text { (Barreto-Rodrigues et al. 2017) } \\
\text { (Aneggi et al. 2017) }\end{array}$ \\
$\mathrm{Ag} / \mathrm{CeO}_{2}$ & 0.01 & 63 & 2 & $70(2 \mathrm{~h})$ & Phenol & 100 & - & (Park et al. 2017) \\
Silver nanoparticles & 0.010 & 0.4 & 4 & $25(8 \mathrm{~h})$ & Bisphenol & 100 & - & (Park et al. 2017) \\
Silver nanoparticles & 0.01 & 0.4 & 4 & $25(8 \mathrm{~h})$ & 17 a-ethinyl estradiol & 100 & - & \\
\hline
\end{tabular}


being predominantly acidic will acidify the aqueous medium and silver will start leaching out from the solid surface:

$2 \mathrm{Ag}+\mathrm{H}_{2} \mathrm{O}_{2} \rightarrow 2 \mathrm{Ag}^{+}+2 \mathrm{OH}^{-}$

$2 \mathrm{Ag}^{+}+\mathrm{OH}^{-}+\mathrm{HO}_{2}^{-} \rightarrow 2 \mathrm{Ag}+\mathrm{O}_{2}+\mathrm{H}_{2} \mathrm{O}$

These drawbacks associated with silver can be averted by incorporating an appropriate support material such as ceria, zirconia, etc. The integration of silver on supports with oxygen storage capacity will not only enhance its activity but also strengthen the catalytic structure because of dual redox cycle, one responsible for activity and the other for stability (Fig. 8). Moreover, surface area is also increased manifold by the introduction of supports which will ultimately increase the activity of the catalyst. Further, the catalyst can afford viable activities through broader $\mathrm{pH}$ range due to dual redox cycle.

The oxidant dose directly affects the silver-catalyzed heterogeneous Fenton process; however, only a small excess of stoichiometric oxidant dose is sufficient to achieve optimal efficacy. Further, a large excess of oxidant dose ought to be avoided because it can either cause scavenging effect or lower the $\mathrm{pH}$ and hence catalytic activity is subdued (Park et al. 2017). The most prominent feature of silver formed catalysts is that they can afford equivalent process efficacies with minimal catalyst loadings.

\section{Cerium}

Cerium is a rare earth metal from lanthanide group which has been widely employed in wet air oxidation and water gas shift reactions (Aneggi et al. 2016; Trovarelli et al. 1999). Owing to its oxidation properties, cerium can conveniently produce $\mathrm{OH}^{\bullet}$ from $\mathrm{H}_{2} \mathrm{O}_{2}$ due to exhibition of two oxidation states, i.e., +3 and +4 . Heckert et al. used cerium-based heterogeneous catalysts for the production of $\mathrm{OH}^{\bullet}$ from $\mathrm{H}_{2} \mathrm{O}_{2}$ through the mechanism outlined in Eq. 17 and 18 (Heckert et al. 2008b). It is important to note that cerous $\left(\mathrm{Ce}^{+3}\right)$ is a strong reducing agent, while ceric $\left(\mathrm{Ce}^{4+}\right)$ is a strong oxidizing agent. These two ions can interchange quite easily, offering a good redox cycle which is critical for heterogeneous Fenton like oxidation (Aneggi et al. 2012; Rossi et al. 2012). A list of studies employing cerium in Fenton-like oxidation is presented in Table 4 .

$$
\begin{aligned}
& \mathrm{Ce}^{3+}+\mathrm{H}_{2} \mathrm{O}_{2} \rightarrow \mathrm{Ce}^{4+}+\mathrm{HO}^{\bullet}+\mathrm{HO}^{-} \\
& \mathrm{Ce}^{4+}+\mathrm{H}_{2} \mathrm{O}_{2} \rightarrow \mathrm{Ce}^{3+}+\mathrm{HO}_{2}^{-}+\mathrm{H}^{+}
\end{aligned}
$$

\section{Controlling parameters}

Unlike other metals, the favorable redox cycle of cerium in aqueous environments is very much dependent on the $\mathrm{pH}$ of the medium. Therefore, $\mathrm{pH}$ of the polluted water is the most critical parameter which governs the activity of cerium catalyst. Under basic conditions, $\mathrm{H}_{2} \mathrm{O}_{2}$ forms very stable peroxide-like species $\left(\mathrm{OOH}^{-}\right)$with cerium (Chen et al. 2012) and these species do not decompose even at neutral $\mathrm{pH}$ conditions; thus, no $\mathrm{OH}^{\bullet}$ radicals are generated at all because the redox cycle between $\mathrm{Ce}^{4+} / \mathrm{Ce}^{3+}$ is completely blocked (Cai et al. 2010; Heckert et al. 2008a; Ji et al. 2010). On the contrary, when acidic conditions are available, the $\mathrm{H}^{+}$ ions attack the cerium-peroxide complex and redox cycle is unblocked which yields $\mathrm{OH}^{\bullet}$ radicals (Fig. 9). However, it is important to note that the cerium-peroxide complex will
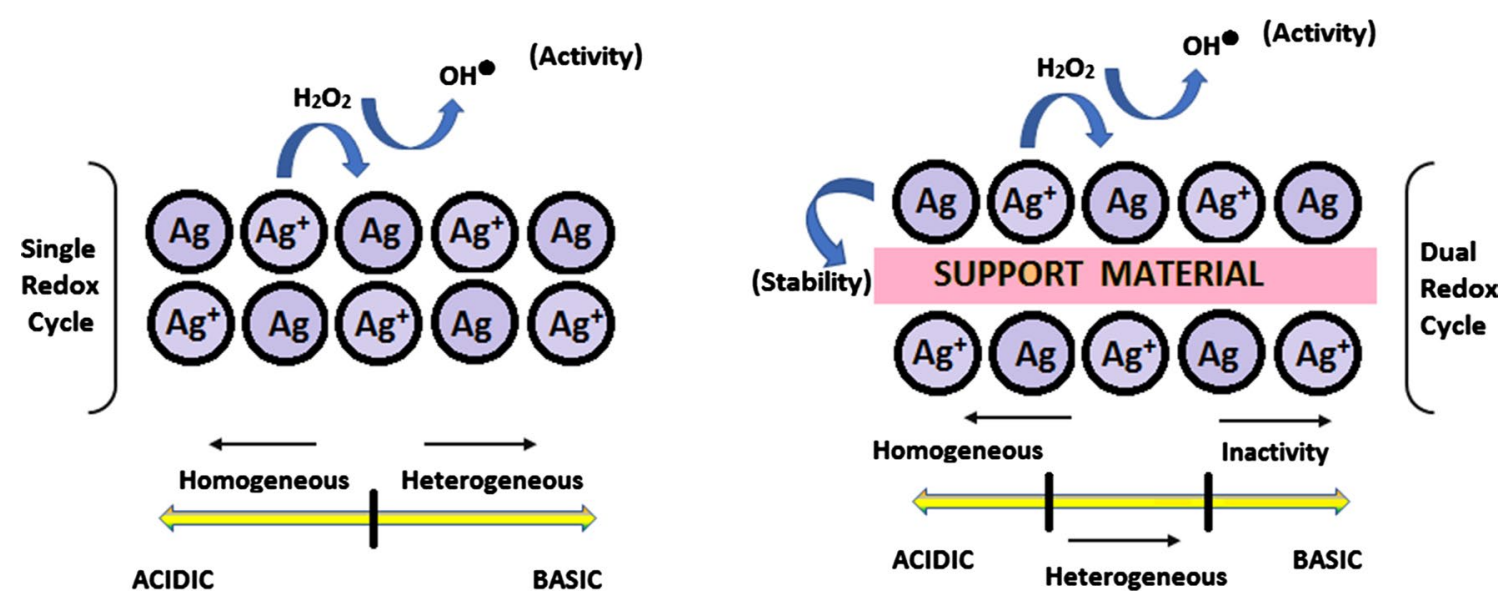

Fig. 8 Activity of bare and supported silver catalysts under variable $\mathrm{pH}$ conditions. Bare silver interacts with $\mathrm{H}_{2} \mathrm{O}_{2}$ forming $\mathrm{OH}^{\bullet}$ radicals through homogeneous phase. The integration of silver on supports enhances its activity and strengthens the stability 
Table 4 Cerium-based catalysts employed in heterogeneous Fenton-like oxidation

\begin{tabular}{|c|c|c|c|c|c|c|c|c|}
\hline Catalyst composition & $\begin{array}{l}\text { Catalyst } \\
\text { dose }(g / 1)\end{array}$ & $\begin{array}{l}\mathrm{H}_{2} \mathrm{O}_{2} \\
\text { dose } \\
(\mathrm{mM} / \mathrm{l})\end{array}$ & $\mathrm{pH}$ & $\mathrm{T}\left({ }^{\circ} \mathrm{C}\right)$ (time) & Target compound & Degradation (\%) & $\begin{array}{l}\text { Miner- } \\
\text { alization } \\
(\%)\end{array}$ & References \\
\hline $\mathrm{CeO}_{2}-\mathrm{LaCuO}_{3}$ & 0.4 & 12.5 & 7 & $25(6 \mathrm{~h})$ & Bisphenol & 99.85 & 72.44 & $\begin{array}{l}\text { (Hammouda et al. } \\
\text { 2017) }\end{array}$ \\
\hline $\mathrm{Ce}-\mathrm{Cu}$ composite oxide & 1 & - & 4 & $50(2 \mathrm{~h})$ & 2,4- Dichlorophenol & 99.5 & 82 & (Xie et al. 2020) \\
\hline $\mathrm{Fe}_{3} \mathrm{O}_{4} / \mathrm{CeO}_{2}$ & 2 & 30 & 2 & $30(1.5 \mathrm{~h})$ & 2,4,6-trichlorophenol & 99 & 65 & (Xu and Wang 2015) \\
\hline $\mathrm{CeO}_{2}$ & 0.5 & 10 & - & $25(8 \mathrm{~h})$ & Acid orange 7 & 98 & - & (Chen et al. 2012) \\
\hline $\mathrm{Ce}-\mathrm{Cu}$ composite oxide & 1 & - & 4 & $50(2 \mathrm{~h})$ & 4- Chlorophenol & 95 & 88 & (Xie et al. 2020) \\
\hline $\mathrm{CexCuOy}$ & 0.1 & 50 & 5 & $25(1 \mathrm{~h})$ & Fluconazole & 94 & - & (Zhang et al. 2020b) \\
\hline $\mathrm{CeO}_{2}$ & 1 & 18 & - & $25(5 \mathrm{~h})$ & Acid orange 7 & 90 & - & (Ji et al. 2010) \\
\hline $\mathrm{Fe}^{0} / \mathrm{CeO}_{2}$ & 0.1 & 100 & 5.8 & $26(1 \mathrm{~h})$ & tetracycline & 90 & - & (Zhang et al. 2019) \\
\hline $\mathrm{FeCeO}_{\mathrm{x}}$ & 1.5 & 80 & 5 & $35(2.5 \mathrm{~h})$ & Rhodamine B & 90 & - & (Zhang et al. 2020a) \\
\hline $\mathrm{CeO}_{2}$ & 1.5 & 60 & 3 & $22(2 \mathrm{~h})$ & Orange II & 85 & - & (Hamoud et al. 2017) \\
\hline $\mathrm{Fe}_{2} \mathrm{O}_{3}-\mathrm{CeO}_{2}$ & 0.5 & 8 & 3 & $45(2 \mathrm{~h})$ & Sulfamerazine & 70 & - & (Gao et al. 2019) \\
\hline $\mathrm{CeO}_{2}$ & 1.5 & 116 & 3 & $22(2 \mathrm{~h})$ & Acid Green & 60 & - & (Hamoud et al. 2017) \\
\hline
\end{tabular}

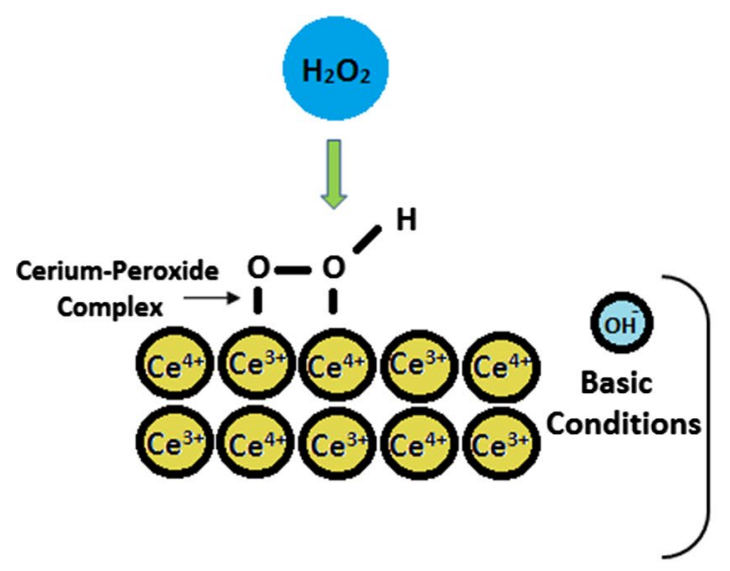

Fig. 9 Cerium reactions with $\mathrm{H}_{2} \mathrm{O}_{2}$ under acidic and basic conditions. Under basic conditions, $\mathrm{H}_{2} \mathrm{O}_{2}$ forms very stable peroxide-like species $\left(\mathrm{OOH}^{-}\right)$with cerium inhibiting $\mathrm{OH}^{*}$ radicals generation, while in

form under both conditions and will only decompose when acidic conditions are applied.

Apart from using an experimentally determined optimal dose of oxidant, it is also crucial to use it in a suitable processing fashion which favors the Fenton oxidation; i.e., oxidant should never be premixed with the cerium catalyst because it is highly likely that it will block the catalytic activity (Heckert et al. 2008a). Therefore, it is viable to employ the oxidant as a last processing step so that part of the cerium catalyst sites is preoccupied by the organics and partly by cerium-peroxide complexes. Further, higher oxidant dose will only intensify the blockage of catalytic activity of cerium. The cerium-peroxide complexes are reverted by acidic conditions or either by applying very high temperatures $\sim 300^{\circ} \mathrm{C}$ (Ferrizz et al. 2001; Liu et al. 2009). Since an increase in temperature is beneficial in reversing

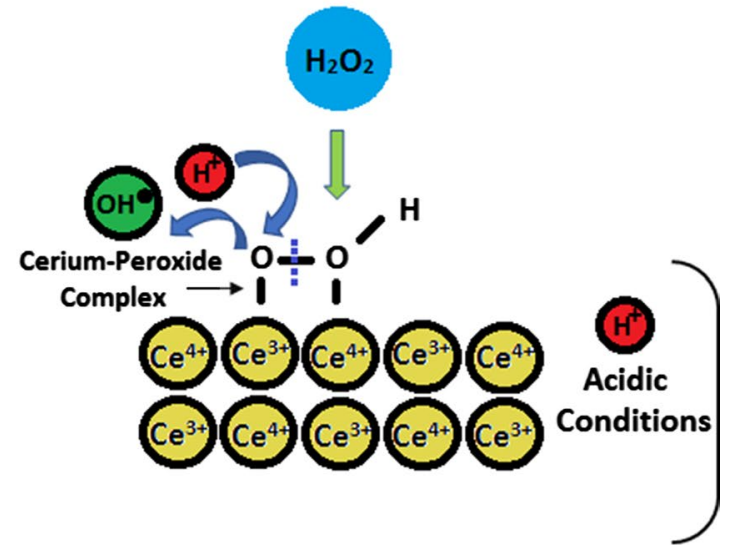

acidic conditions, $\mathrm{H}^{+}$ions attack the cerium-peroxide complex with $\mathrm{OH}^{\bullet}$ radicals generation

the cerium-peroxide complex which triggers the redox cycle $\mathrm{Ce}^{4+} / \mathrm{Ce}^{3+}$, any elevation in temperature would certainly enhance the heterogeneous activity of cerium catalyst (Ferrizz et al. 2001).

\section{Manganese}

Manganese is a transition metal, which is abundantly available, has low toxicity, is not very expensive, and exists in multiple oxidation states (Ren et al. 2012). Manganese offers structural flexibility in its metallic oxides while exhibiting the favorable oxidation states (Birkner et al. 2013). However, $\mathrm{Mn}^{+2}$ and $\mathrm{Mn}^{+4}$ are the only suitable oxidation states while considering heterogeneous Fenton-like oxidation as reported in many studies (Table 5) (Robinson et al. 2013). It is important to mention that manganese transforms $\mathrm{H}_{2} \mathrm{O}_{2}$ into $\mathrm{OH}^{\bullet}$ 
Table 5 Manganese-based heterogeneous catalysts used in Fenton-like oxidation

\begin{tabular}{|c|c|c|c|c|c|c|c|c|}
\hline Catalyst composition & $\begin{array}{l}\text { Catalyst } \\
\text { dose } \\
(\mathrm{g} / 1)\end{array}$ & $\begin{array}{l}\mathrm{H}_{2} \mathrm{O}_{2} \\
\text { dose } \\
(\mathrm{mM} / \mathrm{l})\end{array}$ & $\mathrm{pH}$ & $\mathrm{T}\left({ }^{\circ} \mathrm{C}\right)$ (time) & Target compound & Degradation (\%) & $\begin{array}{l}\text { Miner- } \\
\text { alization } \\
(\%)\end{array}$ & References \\
\hline $\mathrm{Mn}_{3} \mathrm{O}_{4} /$ silicate & 0.4 & 97 & 6 & $25(4 \mathrm{~h})$ & Methylene blue & 100 & 81 & (Tušar et al. 2012) \\
\hline Fe/Mn-MOF-71 & 0.064 & 600 & 6.2 & $35(3 \mathrm{~h})$ & Phenol & 100 & - & (Sun et al. 2017) \\
\hline $\mathrm{MnO}_{2}-\mathrm{MWCNT}$ & 0.2 & 300 & 6 & $25(3 \mathrm{~h})$ & reactive blue 19 & 99 & - & (Fathy et al. 2013) \\
\hline $\mathrm{MnO}_{2}$ & 0.1 & 1450 & 6.1 & $25(0.3 \mathrm{~h})$ & Methylene blue & 99 & - & (Kim et al. 2017) \\
\hline $\mathrm{Mn}_{3} \mathrm{O}_{4}-\mathrm{FeS}_{2} / \mathrm{Fe}_{2} \mathrm{O}_{3}$ & 0.3 & 5 & 2.8 & $25(1 \mathrm{~h})$ & Orange II & 99 & - & (Xu et al. 2020) \\
\hline $\begin{array}{l}\mathrm{Fe}-\mathrm{Mn} \text { oxide hollow fiber } \\
\text { membrane }\end{array}$ & - & 22 & 9 & 25 & Methylene blue & 97 & - & (Xu et al. 2019) \\
\hline $\begin{array}{l}\text { Diatomite/Manganese } \\
\text { silicate }\end{array}$ & 0.3 & 30 & - & $30(1 \mathrm{~h})$ & Malachite green & 93 & - & (Jiang et al. 2018) \\
\hline Mn/Ti-HMS & 1 & 10 & 7 & $25(2 \mathrm{~h})$ & Methylene blue & 63.9 & - & (Song et al. 2016) \\
\hline Mesoporous $\mathrm{MnO}_{\mathrm{x}}$ & 1 & 20 & 3 & $20(1 \mathrm{~h})$ & Norfloxacin(NFX) & 60 & - & (Minghao et al. 2013) \\
\hline Mn/Ti-HMS & 1 & 10 & 7 & $25(2 \mathrm{~h})$ & Rhodamine B & 49.7 & - & (Song et al. 2016) \\
\hline
\end{tabular}

radicals by undergoing through a transitional intermediate, i.e., $\mathrm{Mn}^{+3}$ (Rhadfi et al. 2010; Sigel 2000; Watts et al. 2005), thus possessing a unique redox cycles depending upon the type of oxide, and an electron is exchanged between the substrate and the solution (Fig. 10) (Parida et al. 2005).

\section{Controlling parameters}

The most critical parameter which dictates the efficacy of manganese catalyzed Fenton oxidation is the $\mathrm{pH}$ of the aqueous medium because the $\mathrm{pH}$ conditions change altogether when $\mathrm{MnO}_{2}$ and $\mathrm{Mn}_{3} \mathrm{O}_{4}$ are used (Fig. 10). When $\mathrm{Mn}_{3} \mathrm{O}_{4}$ is employed, the reaction is favored by a basic environment (Eqs. 19 and 20), though neutral conditions are applied for practical reasons:

$$
\begin{aligned}
& \mathrm{Mn}^{+2}+\mathrm{H}_{2} \mathrm{O}_{2} \rightarrow \mathrm{Mn}^{3+}+\mathrm{HO}^{\bullet}+\mathrm{HO}^{-} \\
& \mathrm{Mn}^{+3}+\mathrm{H}_{2} \mathrm{O}_{2} \rightarrow \mathrm{Mn}^{+2}+\mathrm{HO}_{2}^{\bullet}+\mathrm{H}^{+}
\end{aligned}
$$

Conversely, $\mathrm{MnO}_{2}$ requires acidic conditions to drive the redox cycle toward $\mathrm{Mn}^{+3}$ generation which in turn transforms $\mathrm{H}_{2} \mathrm{O}_{2}$ into $\mathrm{OH}^{\bullet}$ radicals (Eqs. 21 and 22). Additionally, precise control of the $\mathrm{pH}$ is also essential because adsorption of organics over the catalyst surface is influenced by it (Zhao et al. 2013). Moreover, the oxidation pathway of organics as well as stability of the catalyst heavily relies on the $\mathrm{pH}$ :

$\mathrm{Mn}^{+4}+\mathrm{H}_{2} \mathrm{O}_{2} \rightarrow \mathrm{Mn}^{3+}+\mathrm{HO}_{2}^{\cdot}+\mathrm{H}^{+}$

$\mathrm{Mn}^{+3}+\mathrm{H}_{2} \mathrm{O}_{2} \rightarrow \mathrm{Mn}^{+4}+\mathrm{HO}^{\bullet}+\mathrm{OH}^{-}$

In the case of manganese-based catalysts, another parameter which greatly influences their performance in Fenton-like process is their morphology (Hermanek et al. 2007; Kim et al. 2017). For instance, $\mathrm{MnO}_{2}$ can exist in four crystalline structures, i.e., $\alpha-\mathrm{MnO}_{2}, \beta-\mathrm{MnO}_{2}$, $\gamma-\mathrm{MnO}_{2}, \delta-\mathrm{MnO}_{2}$. All of them have different surface areas and extents of crystallinity, thus exhibiting variable
Fig. 10 Redox cycles of $\mathrm{MnO}_{2}$ and $\mathrm{Mn}_{3} \mathrm{O}_{4}$ under feasible conditions. Manganese transforms $\mathrm{H}_{2} \mathrm{O}_{2}$ into $\mathrm{OH}^{*}$ radicals by undergoing through a transitional intermediate, i.e., $\mathrm{Mn}^{+3}$
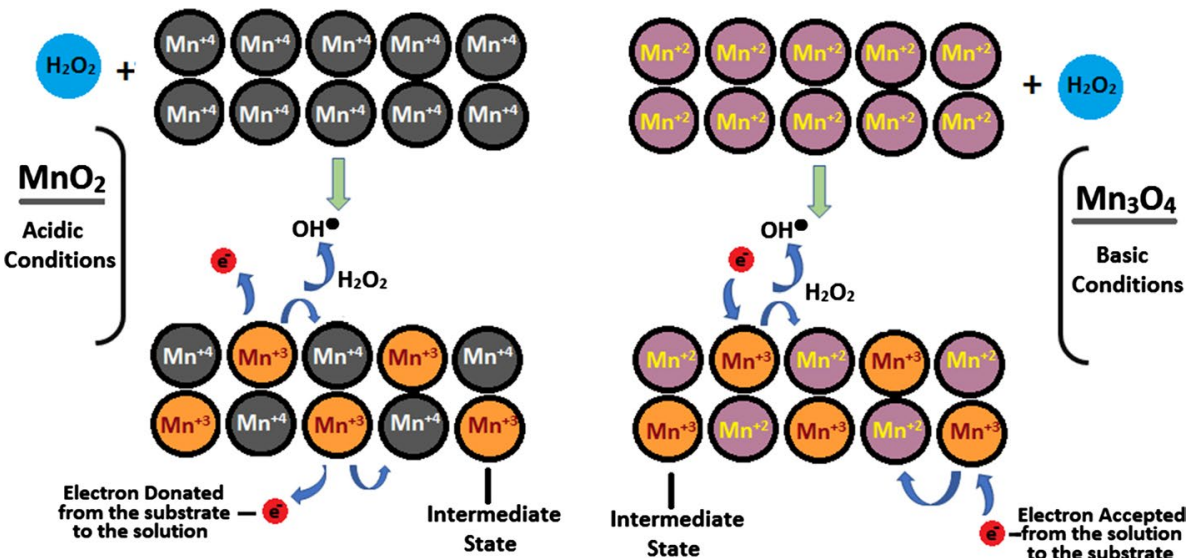
catalytic activities in heterogeneous Fenton process (Xiao et al. 2010). $\gamma-\mathrm{MnO}_{2}$ affords maximum activity because of well-formed morphology and high surface area, while $\delta-\mathrm{MnO}_{2}$ is the least active because it is an amorphous solid with minimum surface area (Kim et al. 2017). Kim et.al. also explained that different morphologies of $\mathrm{MnO}_{2}$ have different magnetic moments, indicating that these oxides exhibit mixed oxidation states (Kim et al. 2017).

$\mathrm{H}_{2} \mathrm{O}_{2}$ dose has a direct impact on the efficacy of manganese-driven Fenton-like process because more oxidant is available for $\mathrm{OH}^{\bullet}$ radical generation. However, an optimal oxidant dose has always to be determined experimentally because excess dose may give rise to scavenging effect which negatively affects the process efficiency. Moreover, any excessive oxidant dose may also disturb the $\mathrm{pH}$ balance of the solution which may suppress the activity of the catalyst (Molina et al. 2006). Similarly, increasing the manganese catalyst loading also increases the overall efficiency of the Fenton process due to increase in the number of active sites through which $\mathrm{OH}^{\prime}$ radicals are generated, and organics are attacked. However, beyond a certain point, surplus catalyst starts moderating the potency of the process due to scavenging effect and aggregation of the material which reduces the exposed active sites of the catalyst. In accordance with Arrhenius law, a rise in temperature elevates the activity of manganese catalyst because lower amount of activation energy is required for product formation (Xiao et al. 2010).

\section{Conclusion}

The inborn limitations of classical Fenton process such as large volumes of sludge and stringent $\mathrm{pH}$ prerequisites can be easily reverted by adapting heterogeneous Fenton-like approach, employing either iron or other metallic systems. The choice of an appropriate metal not only offers milder $\mathrm{pH}$ conditions but also greatly enhances the efficacy of the Fenton process by providing alternate and better redox cycle. In this review, we have discussed different metals and their suitability in Fenton process, considering all the processing factors (Fig. 11). Iron-based catalysts require severe acidic conditions, high catalyst doses, they form stable complexes with oxidation products, and complete mineralization of organics is difficult to achieve. However, these catalysts can bear optimum activities with minimal $\mathrm{H}_{2} \mathrm{O}_{2}$ excess and the energy required to produce oxidizing species is the lowest among the discussed metals. Although silver-based catalysts require less excess $\mathrm{H}_{2} \mathrm{O}_{2}$, low catalyst loadings for optimal performance, a poor redox cycle coupled with susceptibility toward leaching limits their application in Fenton process unless a proper support is employed. Cerium-based catalysts form very stable complexes with the oxidant and can only be broken if stringent acidic conditions are applied. Besides, they require the highest catalyst loadings and excess $\mathrm{H}_{2} \mathrm{O}_{2}$. Copper and manganese both possess superior redox cycles, require feasible catalyst loadings, excess $\mathrm{H}_{2} \mathrm{O}_{2}$ and can afford optimum activities under flexible $\mathrm{pH}$ conditions, and they have the ability to completely mineralize the organics.
Fig. 11 Comparative analysis of metals in heterogeneous Fenton-like oxidation. Several processing factors are considered for metal suitability in Fenton process

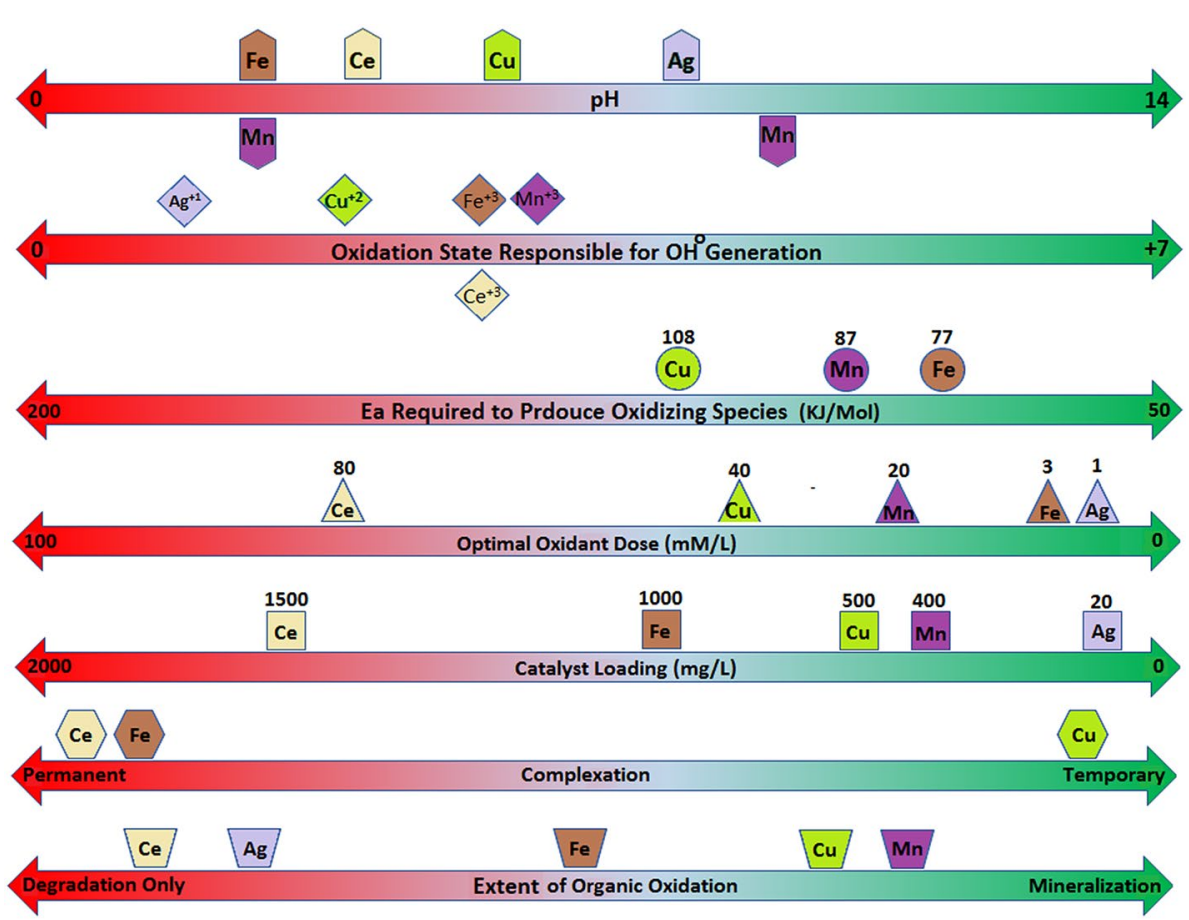


Authors' contributions Open Access funding provided by Università degli Studi di Udine. S.H. performed the literature search and data analysis and drafted the work. E. A. had the idea for the article and critically revised the work. D. G. had the idea for the article and revised the work.

Funding Open access funding provided by Università degli Studi di Udine within the CRUI-CARE Agreement.

Code availability Not applicable.

\section{Compliance with ethical standards}

Conflicts of interest The authors declare that they have no competing interests.

Open Access This article is licensed under a Creative Commons Attribution 4.0 International License, which permits use, sharing, adaptation, distribution and reproduction in any medium or format, as long as you give appropriate credit to the original author(s) and the source, provide a link to the Creative Commons licence, and indicate if changes were made. The images or other third party material in this article are included in the article's Creative Commons licence, unless indicated otherwise in a credit line to the material. If material is not included in the article's Creative Commons licence and your intended use is not permitted by statutory regulation or exceeds the permitted use, you will need to obtain permission directly from the copyright holder. To view a copy of this licence, visit http://creativecommons.org/licenses/by/4.0/.

\section{References}

Andreozzi R, Caprio V, Insola A, Marotta R (1999) Advanced oxidation processes (AOP) for water purification and recovery Catalysis. Today 53:51-59. https://doi.org/10.1016/S0920-5861(99) 00102-9

Aneggi E, Cabbai V, Trovarelli A, Goi D (2012) Potential of CeriaBased Catalysts for the Oxidation of Landfill Leachate by Heterogeneous Fenton Process Artn 694721 https://doi.org/10.1155/ 2012/694721

Aneggi E, Boaro M, Colussi S, de Leitenburg C, Trovarelli A (2016) Ceria-Based Materials in Catalysis: Historical Perspective and Future Trends Handbook on the Physics and Chemistry of Rare Earths 50: 209-242 https://doi.org/10.1016/bs.hpcre.2016.05.002

Aneggi E, Trovarelli A, Goi D (2017) Degradation of phenol in wastewaters via heterogeneous Fenton-like $\mathrm{Ag} / \mathrm{CeO}_{2}$ catalyst. J Environ Chem Eng 5:1159-1165. https://doi.org/10.1016/j.jece.2017. 01.042

Araujo F, Yokoyama L, Teixeira L, Campos J (2011) Heterogeneous Fenton process using the mineral hematite for the discolouration of a reactive dye solution. Braz J Chem Eng 28:605-616. https:// doi.org/10.1590/S0104-66322011000400006

Asci Y (2013) Decolorization of Direct Orange 26 by heterogeneous Fenton oxidation. Desalination and Water Treatment, 51: 76127620 https://doi.org/10.1080/19443994.2013.776504

Ayoub $\mathrm{H}$ et al (2018) Iron-impregnated zeolite catalyst for efficient removal of micropollutants at very low concentration from Meurthe river. Environ Sci Pollut Res 25:34950-34967. https:// doi.org/10.1007/s11356-018-1214-0

Aziz AA, Daud WMAW (2012) Oxidative mineralisation of petroleum refinery effluent using Fenton-like process. Chem Eng Res Design 90:298-307. https://doi.org/10.1016/j.cherd.2011.06.010
Bali U, Karagözoğlu B (2007) Performance comparison of Fenton process, ferric coagulation and $\mathrm{H}_{2} \mathrm{O}_{2} /$ pyridine/Cu(II) system for decolorization of Remazol Turquoise Blue G-133. Dyes pigments 74:73-80. https://doi.org/10.1016/j.dyepig.2006.01.013

Barbusiński K (2009) Henry John Horstman Fenton-short biography and brief history of Fenton reagent discovery. Chem Didact Ecol Metrol 14:101

Barhoumi N, Oturan N, Ammar S, Gadri A, Oturan MA, Brillas E (2017) Enhanced degradation of the antibiotic tetracycline by heterogeneous electro-Fenton with pyrite catalysis. Environ Chem Lett 15:689-693. https://doi.org/10.1007/ s10311-017-0638-y

Barreto-Rodrigues M, Silveira J, García-Muñoz P, Rodriguez JJ (2017) Dechlorination and oxidative degradation of 4-chlorophenol with nanostructured iron-silver alginate beads. J Environ Chem Eng 5:838-842. https://doi.org/10.1016/j.jece. 2016.12.051

Bautista P, Mohedano A, Casas J, Zazo J, Rodriguez J (2008) An overview of the application of Fenton oxidation to industrial wastewaters treatment. J Chem Technol Biotechnol: Int Res Process, Environ Clean Technol 83:1323-1338. https://doi.org/10.1002/ jctb. 1988

Bayat M, Sohrabi M, Royaee SJ (2012) Degradation of phenol by heterogeneous Fenton reaction using Fe/clinoptilolite. J Ind Eng Chem 18:957-962. https://doi.org/10.1016/j.jiec.2011.09.004

Bello MM, Raman AAA (2019) Synergy of adsorption and advanced oxidation processes in recalcitrant wastewater treatment. Environ Chem Lett 17:1125-1142. https://doi.org/10.1007/ s10311-018-00842-0

Birkner N, Nayeri S, Pashaei B, Najafpour MM, Casey WH, Navrotsky A (2013) Energetic basis of catalytic activity of layered nanophase calcium manganese oxides for water oxidation. Proc Natl Acad Sci 110:8801-8806. https://doi.org/10.1073/pnas.13066 23110

Bobu M, Yediler A, Siminiceanu I, Schulte-Hostede S (2008) Degradation studies of ciprofloxacin on a pillared iron catalyst. Appl Catal B 83:15-23. https://doi.org/10.1016/j.apcatb.2008.01.029

Boczkaj G, Fernandes A (2017) Wastewater treatment by means of advanced oxidation processes at basic $\mathrm{pH}$ conditions: a review. Chem Eng J 320:608-633. https://doi.org/10.1016/j.cej.2017. 03.084

Bokare AD, Choi W (2014) Review of iron-free Fenton-like systems for activating $\mathrm{H}_{2} \mathrm{O}_{2}$ in advanced oxidation processes. J Hazard Mater 275:121-135. https://doi.org/10.1016/j.jhazmat.2014.04. 054

Bradu C, Frunza L, Mihalche N, Avramescu S-M, Neaţă M, Udrea I (2010) Removal of Reactive Black 5 azo dye from aqueous solutions by catalytic oxidation using $\mathrm{CuO} / \mathrm{Al}_{2} \mathrm{O}_{3}$ and $\mathrm{NiO} / \mathrm{Al}_{2} \mathrm{O}_{3}$. Appl Catal B: Environ 96:548-556. https://doi.org/10.1016/j. apcatb.2010.03.019

Brillas E, Sirés I, Oturan MA (2009) Electro-Fenton process and related electrochemical technologies based on Fenton's reaction chemistry. Chem Rev 109:6570-6631. https://doi.org/10.1021/ cr900136g

Buxton GV, Greenstock CL, Helman WP, Ross AB (1988) Critical review of rate constants for reactions of hydrated electrons, hydrogen atoms and hydroxyl radicals $(\cdot \mathrm{OH} / \cdot \mathrm{O}-$ in aqueous solution. J Phys Chem Refer Data 17:513-886. https://doi.org/ 10.1063/1.555805

Cai W, Chen F, Shen X, Chen L, Zhang J (2010) Enhanced catalytic degradation of $\mathrm{AO} 7$ in the $\mathrm{CeO}_{2}-\mathrm{H}_{2} \mathrm{O}_{2}$ system with $\mathrm{Fe}^{3+}$ doping. Appl Catal B: Environ 101:160-168. https://doi.org/10.1016/j. apcatb.2010.09.031

Caudo S, Centi G, Genovese C, Perathoner S (2006) Homogeneous versus heterogeneous catalytic reactions to eliminate organics from 
waste water using $\mathrm{H}_{2} \mathrm{O}_{2}$. Topics Catalysis 40:207-219. https:// doi.org/10.1007/s11244-006-0122-6

Centi G, Perathoner S, Torre T, Verduna MG (2000) Catalytic wet oxidation with $\mathrm{H}_{2} \mathrm{O}_{2}$ of carboxylic acids on homogeneous and heterogeneous Fenton-type Catalysts. Catal Today 55:61-69. https://doi.org/10.1016/S0920-5861(99)00226-6

Chan YJ, Chong MF, Law CL, Hassell D (2009) A review on anaerobic-aerobic treatment of industrial and municipal wastewater. Chem Eng J 155:1-18. https://doi.org/10.1016/j.cej.2009.06. 041

Chen F, Shen X, Wang Y, Zhang J (2012) $\mathrm{CeO}_{2} / \mathrm{H}_{2} \mathrm{O}_{2}$ system catalytic oxidation mechanism study via a kinetics investigation to the degradation of acid orange 7. Appl Catal B: Environ 121:223229. https://doi.org/10.1016/j.apcatb.2012.04.014

Chen H, Zhang L, Zeng H, Yin D, Zhai Q, Zhao X, Li J (2015a) Highly active iron-containing silicotungstate catalyst for heterogeneous Fenton oxidation of 4-chlorophenol. J Mol Catal A: Chem 406:72-77. https://doi.org/10.1016/j.cej.2015.03.079

Chen H, Zhang Z, Yang Z, Yang Q, Li B, Bai Z (2015b) Heterogeneous fenton-like catalytic degradation of 2, 4-dichlorophenoxyacetic acid in water with FeS. Chem Eng J 273:481-489. https://doi. org/10.1016/j.molcata.2015.05.017

Cihanoğlu A, Gündüz G, Dükkanc1 M (2015) Degradation of acetic acid by heterogeneous Fenton-like oxidation over iron-containing ZSM-5 zeolites. Appl Catal B: Environ 165(6):87-699. https:// doi.org/10.1016/j.apcatb.2014.10.073

Comninellis C, Kapalka A, Malato S, Parsons SA, Poulios I, Mantzavinos D (2008) Advanced oxidation processes for water treatment: advances and trends for R\&D. J Chem Technol Biotechnol: Int Res Process, Environ Clean Technol 83:769-776. https://doi.org/ $10.1002 /$ jctb. 1873

Costa RC, Moura FC, Ardisson J, Fabris J, Lago R (2008) Highly active heterogeneous Fenton-like systems based on $\mathrm{Fe} 0 / \mathrm{Fe}_{3} \mathrm{O}_{4}$ composites prepared by controlled reduction of iron oxides. Appl Catal B: Environ 83:131-139. https://doi.org/10.1016/j.apcatb. 2008.01.039

de la Plata GBO, Alfano OM, Cassano AE (2010) Decomposition of 2-chlorophenol employing goethite as Fenton catalyst. I. Proposal of a feasible, combined reaction scheme of heterogeneous and homogeneous reactions. Appl Catal B: Environ 95:1-13. https://doi.org/10.1016/j.apcatb.2009.12.005

Deng Y, Englehardt JD (2006) Treatment of landfill leachate by the Fenton process. Water Res 40:3683-3694. https://doi.org/10. 1016/j.watres.2006.08.009

Deng J, Jiang J, Zhang Y, Lin X, Du C, Xiong Y (2008) $\mathrm{FeVO}_{4}$ as a highly active heterogeneous Fenton-like catalyst towards the degradation of Orange II. Appl Catal B: Environ 84:468-473. https://doi.org/10.1016/j.apcatb.2008.04.029

Deng J, Wen X, Wang Q (2012) Solvothermal in situ synthesis of $\mathrm{Fe}_{3} \mathrm{O}_{4}$-multi-walled carbon nanotubes with enhanced heterogeneous Fenton-like activity. Mater Res Bullet 47:3369-3376. https:// doi.org/10.1016/j.materresbull.2012.07.021

Dhakshinamoorthy A, Navalon S, Alvaro M, Garcia H (2012) Metal nanoparticles as heterogeneous Fenton catalysts. Chemsuschem 5:46-64. https://doi.org/10.1002/cssc.201100517

Divya T, Renuka N (2015) Modulated heterogeneous Fenton-like activity of 'M'doped nanoceria systems $(\mathrm{M}=\mathrm{Cu}, \mathrm{Fe}, \mathrm{Zr}$, Dy, La): Influence of reduction potential of doped cations. J Mol Catal A: Chem 408:41-47. https://doi.org/10.1016/j.molcata.2015.07.018

Do QC, Kim D-G, Ko S-O (2018) Catalytic activity enhancement of a $\mathrm{Fe}_{3} \mathrm{O}_{4} @ \mathrm{SiO}_{2}$ yolk-shell structure for oxidative degradation of acetaminophen by decoration with copper. J Clean Prod 172:1243-1253. https://doi.org/10.1016/j.jclepro.2017.10.246

Duarte F, Maldonado-Hodar F, Madeira LM (2012) Influence of the particle size of activated carbons on their performance as $\mathrm{Fe}$ supports for developing Fenton-like catalysts. Ind Eng Chem Res 51:9218-9226. https://doi.org/10.1021/ie300167r

Dükkancı M, Gündüz G, Yılmaz S, Yaman Y, Prikhod'Ko R, Stolyarova I (2010) Characterization and catalytic activity of CuFeZSM-5 catalysts for oxidative degradation of Rhodamine 6G in aqueous solutions. Appl Catal B: Environ 95:270-278. https://doi.org/10.1016/j.apcatb.2010.01.004

Fakhru Razi A, Pendashteh A, Abdullah LC, Biak DRA, Madaeni SS, Abidin ZZ (2009) Review of technologies for oil and gas produced water treatment. J Hazard Mater 170:530-551. https://doi. org/10.1016/j.jhazmat.2009.05.044

Fathy NA, El-Shafey SE, El-Shafey OI, Mohamed WS (2013) Oxidative degradation of RB19 dye by a novel $\gamma$-MnO2/MWCNT nanocomposite catalyst with $\mathrm{H}_{2} \mathrm{O}_{2}$. J Environ Chem Eng 1:858864. https://doi.org/10.1016/j.jece.2013.07.028

Feng Y, Wu DL, Duan D, Lu MM Fenton-like oxidation of refractory chemical wastewater using pyrite. In: Advanced Materials Research Trans Tech Publ, 518: 2518-2525 https://doi.org/10. 4028/www.scientific.net/AMR.518-523.2518

Feng Y, Wu D, Ma L (2013) Iron oxide catalyzed Fenton-like reaction. Prog Chem 25:1219. https://doi.org/10.7536/PC121143

Fenton H (1894) LXXIII.-Oxidation of tartaric acid in presence of iron Journal of the Chemical Society. Transactions 65:899-910. https://doi.org/10.1039/CT8946500899

Ferrizz R, Wong G, Egami T, Vohs J (2001) Structure sensitivity of the reaction of methanol on ceria. Langmuir 17:2464-2470. https:// doi.org/10.1021/la001729o

Fink L, Dror I, Berkowitz B (2012) Enrofloxacin oxidative degradation facilitated by metal oxide nanoparticles. Chemosphere $86: 144$ 149. https://doi.org/10.1016/j.chemosphere.2011.10.002

Flores Y, Flores R, Gallegos AA (2008) Heterogeneous catalysis in the Fenton-type system reactive black $5 / \mathrm{H}_{2} \mathrm{O}_{2}$. J Mol Catal A: Chem 281:184-191. https://doi.org/10.1016/j.molcata.2007.10.019

Gao P, Chen X, Hao M, Xiao F, Yang S (2019) Oxygen vacancy enhancing the $\mathrm{Fe}_{2} \mathrm{O}_{3}-\mathrm{CeO}_{2}$ catalysts in Fenton-like reaction for the sulfamerazine degradation under $\mathrm{O}_{2}$ atmosphere. Chemosphere 228:521-527. https://doi.org/10.1016/j.chemosphere.2019. 04.125

Garrido-Ramírez E, Theng B, Mora M (2010) Clays and oxide minerals as catalysts and nanocatalysts in Fenton-like reactions-a review. Appl Clay Sci 47:182-192. https://doi.org/10.1016/j.clay. 2009.11.044

Gavrilescu M, Demnerová K, Aamand J, Agathos S, Fava F (2015) Emerging pollutants in the environment: present and future challenges in biomonitoring, ecological risks and bioremediation. New Biotechnol 32:147-156. https://doi.org/10.1016/j.nbt.2014. 01.001

Geçgel Ü, Kocabıyık B, Üner O (2015) Adsorptive removal of methylene blue from aqueous solution by the activated carbon obtained from the fruit of catalpa bignonioides Water. Air, Soil Pollut 226:238. https://doi.org/10.1007/s11270-015-2513-4

Glassmeyer ST et al (2005) Transport of chemical and microbial compounds from known wastewater discharges: potential for use as indicators of human fecal contamination. Environ Sci Technol 39:5157-5169. https://doi.org/10.1021/es048120k

Glaze WH, Kang JW (1989) Advanced oxidation processes. Test of a kinetic model for the oxidation of organic compounds with ozone and hydrogen peroxide in a semibatch reactor. Ind Eng Chem Res 28:1580-1587. https://doi.org/10.1021/ie00095a002

Gogate PR, Pandit AB (2004) A review of imperative technologies for wastewater treatment I: oxidation technologies at ambient conditions. Adv Environ Res 8:501-551. https://doi.org/10.1016/ S1093-0191(03)00032-7 
Goldstein S, Meyerstein D, Czapski G (1993) The fenton reagents. Free Radic Biol Med 15:435-445. https://doi.org/10.1016/08915849(93)90043-T

Gonzalez-Olmos R, Holzer F, Kopinke F-D, Georgi A (2011) Indications of the reactive species in a heterogeneous Fenton-like reaction using Fe-containing zeolites. Appl Catal A 398:44-53. https://doi.org/10.1016/j.apcata.2011.03.005

Gumy D, Fernández-Ibáñez P, Malato S, Pulgarin C, Enea O, Kiwi J (2005) Supported Fe/C and Fe/Nafion/C catalysts for the photoFenton degradation of Orange II under solar irradiation. Catal Today 101:375-382. https://doi.org/10.1016/j.cattod.2005.03. 036

Hammouda SB, Zhao F, Safaei Z, Babu I, Ramasamy DL, Sillanpää M (2017) Reactivity of novel Ceria-Perovskite composites CeO2LaMO3 $(\mathrm{MCu}, \mathrm{Fe})$ in the catalytic wet peroxidative oxidation of the new emergent pollutant 'Bisphenol F': Characterization, kinetic and mechanism studies. Appl Catal B: Environ 218:119136. https://doi.org/10.1016/j.apcatb.2017.06.047

Hamoud HI, Finqueneisel G, Azambre B (2017) Removal of binary dyes mixtures with opposite and similar charges by adsorption, coagulation/flocculation and catalytic oxidation in the presence of $\mathrm{CeO}_{2} / \mathrm{H}_{2} \mathrm{O}_{2}$ Fenton-like system. J Environ Manage 195:195207. https://doi.org/10.1016/j.jenvman.2016.07.067

Hanna K, Kone T, Medjahdi G (2008) Synthesis of the mixed oxides of iron and quartz and their catalytic activities for the Fenton-like oxidation. Catal Commun 9:955-959. https://doi.org/10.1016/j. catcom.2007.09.035

Hartmann M, Kullmann S, Keller H (2010) Wastewater treatment with heterogeneous Fenton-type catalysts based on porous materials. J Mater Chem 20:9002-9017. https://doi.org/10.1039/C0JM0 $0577 \mathrm{~K}$

Hassan H, Hameed B (2011a) Fe-clay as effective heterogeneous Fenton catalyst for the decolorization of Reactive Blue 4. Chem Eng J 171:912-918. https://doi.org/10.1016/j.cej.2011.04.040

Hassan H, Hameed B (2011b) Oxidative decolorization of Acid Red 1 solutions by Fe-zeolite Y type catalyst. Desalination 276:45-52. https://doi.org/10.1016/j.desal.2011.03.018

He W, Zhou Y-T, Wamer WG, Boudreau MD, Yin J-J (2012) Mechanisms of the $\mathrm{pH}$ dependent generation of hydroxyl radicals and oxygen induced by Ag nanoparticles. Biomaterials 33:75477555. https://doi.org/10.1016/j.biomaterials.2012.06.076

He J, Yang X, Men B, Wang D (2016) Interfacial mechanisms of heterogeneous Fenton reactions catalyzed by iron-based materials: A review. J Environ Sci 39:97-109. https://doi.org/10.1016/j.jes. 2015.12.003

Heckert EG, Karakoti AS, Seal S, Self WT (2008a) The role of cerium redox state in the SOD mimetic activity of nanoceria. Biomaterials 29:2705-2709. https://doi.org/10.1016/j.biomaterials.2008. 03.014

Heckert EG, Seal S, Self WT (2008b) Fenton-like reaction catalyzed by the rare earth inner transition metal cerium. Environ Sci Technol 42:5014-5019. https://doi.org/10.1021/es8001508

Hermanek M, Zboril R, Medrik I, Pechousek J, Gregor C (2007) Catalytic efficiency of iron (III) oxides in decomposition of hydrogen peroxide: competition between the surface area and crystallinity of nanoparticles. J Am Chem Soc 129:10929-10936. https://doi. org/10.1021/ja072918x

Herney-Ramirez J, Lampinen M, Vicente MA, Costa CA, Madeira LM (2008) Experimental design to optimize the oxidation of Orange II dye solution using a clay-based Fenton-like catalyst. Ind Eng Chem Res 47:284-294. https://doi.org/10.1021/ie070990y

Huang C, Dong C, Tang Z (1993) Advanced chemical oxidation: its present role and potential future in hazardous waste treatment.
Waste Manage 13:361-377. https://doi.org/10.1016/0956053X(93)90070-D

Huanosta-Gutiérrez T, Dantas RF, Ramírez-Zamora R, Esplugas S (2012) Evaluation of copper slag to catalyze advanced oxidation processes for the removal of phenol in water. J Hazard Mater 213:325-330. https://doi.org/10.1016/j.jhazmat.2012.02.004

Hussain S, Aneggi E, Briguglio S, Mattiussi M, Gelao V, Cabras I, Zorzenon L, Trovarelli A, Goi D (2020) Enhanced ibuprofen removal by heterogeneous-Fenton process over $\mathrm{Cu} / \mathrm{ZrO}_{2}$ and $\mathrm{Fe} /$ $\mathrm{ZrO}_{2}$ catalysts. J Environ Chem Eng 8:103586. https://doi.org/ 10.1016/j.jece.2019.103586

Ioannou L, Puma GL, Fatta-Kassinos D (2015) Treatment of winery wastewater by physicochemical, biological and advanced processes: a review. J Hazard Mater 286:343-368. https://doi.org/ 10.1016/j.jhazmat.2014.12.043

Jain B, Singh AK, Kim H, Lichtfouse E, Sharma VK (2018) Treatment of organic pollutants by homogeneous and heterogeneous Fenton reaction processes. Environ Chem Lett 16:947-967. https://doi.org/10.1007/s10311-018-0738-3

Ji P, Wang L, Chen F, Zhang J (2010) Ce3+-centric organic pollutant elimination by $\mathrm{CeO} 2$ in the presence of $\mathrm{H} 2 \mathrm{O} 2$. ChemCatChem 2:1552-1554. https://doi.org/10.1002/cctc.201000191

Jiang DB, Yuan Y, Zhao D, Tao K, Xu X, Zhang YX (2018) Facile synthesis of three-dimensional diatomite/manganese silicate nanosheet composites for enhanced Fenton-like catalytic degradation of malachite green dye. J Nanopart Res 20:123. https://doi.org/10.1007/s11051-018-4226-2

Jin Q, Kang J, Chen Q, Shen J, Guo F, Chen Z (2020) Efficiently enhanced Fenton-like reaction via Fe complex immobilized on silica particles for catalytic hydrogen peroxide degradation of 2, 4-dichlorophenol. Appl Catal B: Environ 268:118453. https://doi.org/10.1016/j.apcatb.2019.118453

John EM, Shaike JM (2015) Chlorpyrifos: pollution and remediation. Environ Chem Lett 13:269-291. https://doi.org/10.1007/ s10311-015-0513-7

Kasprzyk-Hordern B, Dinsdale RM, Guwy AJ (2008) The occurrence of pharmaceuticals, personal care products, endocrine disruptors and illicit drugs in surface water in South Wales. UK Water research 42:3498-3518. https://doi.org/10.1016/j. watres.2008.04.026

Kim SD, Cho J, Kim IS, Vanderford BJ, Snyder SA (2007) Occurrence and removal of pharmaceuticals and endocrine disruptors in South Korean surface, drinking, and waste waters. Water Res 41:1013-1021. https://doi.org/10.1016/j.watres.2006.06. 034

Kim E-J, Oh D, Lee C-S, Gong J, Kim J, Chang Y-S (2017) Manganese oxide nanorods as a robust Fenton-like catalyst at neutral pH: Crystal phase-dependent behavior. Catal Today 282:7176. https://doi.org/10.1016/j.cattod.2016.03.034

Kolpin DW, Furlong ET, Meyer MT, Thurman EM, Zaugg SD, Barber LB, Buxton HT (2002) Pharmaceuticals, hormones, and other organic wastewater contaminants in US streams, 1999-2000: A national reconnaissance Environmental science \& technology 36:1202-1211. https://doi.org/https://doi. org/10.1021/es011055j

Konstantinou IK, Albanis TA (2004) $\mathrm{TiO}_{2}$-assisted photocatalytic degradation of azo dyes in aqueous solution: kinetic and mechanistic investigations: a review. Appl Catal B: Environ 49:1-14. https:// doi.org/10.1016/j.apcatb.2003.11.010

Kundakovic L, Flytzani-Stephanopoulos M (1999) Deep oxidation of methane over zirconia supported Ag catalysts. Appl Catal A 183:35-51. https://doi.org/10.1016/S0926-860X(99)00043-5

Lahkimi A, Oturan MA, Oturan N, Chaouch M (2007) Removal of textile dyes from water by the electro-Fenton process. Environ Chem Lett 5:35-39. https://doi.org/10.1007/s10311-006-0058-x 
Li Y, Zhang F-S (2010) Catalytic oxidation of Methyl Orange by an amorphous $\mathrm{FeOOH}$ catalyst developed from a high iron-containing fly ash. Chem Eng J 158:148-153. https://doi.org/10.1016/j. cej.2009.12.021

Li D, Yang T, Li Y, Liu Z, Jiao W (2020) Facile and green synthesis of highly dispersed tar-based heterogeneous Fenton catalytic nanoparticles for the degradation of methylene blue. J Clean Prod 246:119033. https://doi.org/10.1016/j.jclepro.2019.119033

Lin Z-R, Zhao L, Dong Y-H (2015) Quantitative characterization of hydroxyl radical generation in a goethite-catalyzed Fenton-like reaction. Chemosphere 141:7-12. https://doi.org/10.1016/j. chemosphere.2015.05.066

Liu X, Zhou K, Wang L, Wang B, Li Y (2009) Oxygen vacancy clusters promoting reducibility and activity of ceria nanorods. J Am Chem Soc 131:3140-3141. https://doi.org/10.1021/ja808433d

Lucas MS, Peres JA (2009) Treatment of olive mill wastewater by a combined process: Fenton's reagent and chemical coagulation. J Environ Sci Health Part A 44:198-205. https://doi.org/10. 1080/10934520802539889

Luo M, Bowden D, Brimblecombe P (2009) Catalytic property of $\mathrm{Fe}-\mathrm{Al}$ pillared clay for Fenton oxidation of phenol by $\mathrm{H}_{2} \mathrm{O}_{2}$. Appl Catal B: Environ 85:201-206. https://doi.org/10.1016/j. apcatb.2008.07.013

Luo W, Zhu L, Wang N, Tang H, Cao M, She Y (2010) Efficient removal of organic pollutants with magnetic nanoscaled $\mathrm{BiFeO} 3$ as a reusable heterogeneous Fenton-like catalyst. Environ Sci Technol 44:1786-1791. https://doi.org/10.1021/ es903390g

Lv H, Zhao H, Cao T, Qian L, Wang Y, Zhao G (2015) Efficient degradation of high concentration azo-dye wastewater by heterogeneous Fenton process with iron-based metal-organic framework. J Mol Catal A: Chem 400:81-89. https://doi.org/10.1016/j.molca ta.2015.02.007

Lyu L, Zhang L, Hu C (2015) Enhanced Fenton-like degradation of pharmaceuticals over framework copper species in copper-doped mesoporous silica microspheres. Chem Eng J 274:298-306. https://doi.org/10.1016/j.cej.2015.03.137

Mao C-F, Vannice MA (1995) High surface area $\alpha$-aluminas III. Oxidation of ethylene, ethylene oxide, and acetaldehyde over silver dispersed on high surface area $\alpha$-alumina. Appl Catal A: Gen 122:61-76. https://doi.org/10.1016/0926-860X(94)00214-2

Metz F, Ingold K (2014) Sustainable wastewater management: is it possible to regulate micropollution in the future by learning from the past? A Policy Anal Sustain 6:1992-2012. https://doi.org/10. 3390/su6041992

Miles CJ, Brezonik PL (1981) Oxygen consumption in humic-colored waters by a photochemical ferrous-ferric catalytic cycle. Environ Sci Technol 15:1089-1095. https://doi.org/10.1021/es00091a010

Minghao S, Lei S, Sheng L, Jinjie W, Zhang L, Huang S (2013) Ordered mesoporous manganese oxide as catalyst for hydrogen peroxide oxidation of norfloxacin in water. Chinese $\mathrm{J}$ Catal 34:536-541. https://doi.org/10.1016/S1872-2067(11)60492-0

Molina R, Martínez F, Melero JA, Bremner DH, Chakinala AG (2006) Mineralization of phenol by a heterogeneous ultrasound/FeSBA- $15 / \mathrm{H}_{2} \mathrm{O}_{2}$ process: multivariate study by factorial design of experiments. Appl Catal B: Environ 66:198-207. https://doi.org/ 10.1016/j.apcatb.2006.03.015

Mosteo R, Ormad M, Ovelleiro J (2007) Photo-Fenton processes assisted by solar light used as preliminary step to biological treatment applied to winery wastewaters. Water Sci Technol 56:89-94. https://doi.org/10.2166/wst.2007.476

Mousset E, Dionysiou DD (2020) Photoelectrochemical reactors for treatment of water and wastewater: a review. Environ Chem Lett 18:1301-1318. https://doi.org/10.1007/s10311-020-01014-9
Munoz M, de Pedro ZM, Menendez N, Casas JA, Rodriguez JJ (2013) A ferromagnetic $\gamma$-alumina-supported iron catalyst for CWPO Application to chlorophenols. Appl Catal B: Environ 136:218 224. https://doi.org/10.1016/j.apcatb.2013.02.002

Muthuvel I, Swaminathan M (2008) Highly solar active Fe (III) immobilised alumina for the degradation of Acid Violet 7. Solar Energy Mater Solar Cells 92:857-863. https://doi.org/10.1016/j. solmat.2008.02.007

Nasuha N, Ismail S, Hameed B (2016) Activated electric arc furnace slag as an efficient and reusable heterogeneous Fenton-like catalyst for the degradation of Reactive Black 5. J Taiwan Inst Chem Eng 67:235-243. https://doi.org/10.1016/j.jtice.2016.07.023

Navalon S, Alvaro M, Garcia H (2010) Heterogeneous Fenton catalysts based on clays, silicas and zeolites. Appl Catal B: Environ 99:1-26. https://doi.org/10.1002/cssc.201100216

Navalon S, Dhakshinamoorthy A, Alvaro M, Garcia H (2011) Heterogeneous Fenton catalysts based on activated carbon and related materials. Chemsuschem 4:1712-1730. https://doi.org/10.1016/j. apcatb.2010.07.006

Neyens E, Baeyens J (2003) A review of classic Fenton's peroxidation as an advanced oxidation technique. J Hazard Mater 98:33-50. https://doi.org/10.1016/S0304-3894(02)00282-0

Nidheesh P (2015) Heterogeneous Fenton catalysts for the abatement of organic pollutants from aqueous solution: a review. Rsc Adv 5:40552-40577. https://doi.org/10.1039/C5RA02023A

Nidheesh PV, Gandhimathi R, Ramesh ST (2013) Degradation of dyes from aqueous solution by Fenton processes: a review. Environ Sci Pollut Res 20:2099-2132. https://doi.org/10.1007/ s11356-012-1385-Z

Noyes AA, Whitney WR (1897) The rate of solution of solid substances in their own solutions. J Am Chem Soc 19:930-934. https://doi. org/10.1021/ja02086a003

Oller I, Malato S, Sánchez-Pérez J (2011) Combination of advanced oxidation processes and biological treatments for wastewater decontamination—a review. Sci Total Environ 409:4141-4166. https://doi.org/10.1016/j.scitotenv.2010.08.061

Othman I, Haija MA, Ismail I, Zain JH, Banat F (2019) Preparation and catalytic performance of $\mathrm{CuFe}_{2} \mathrm{O}_{4}$ nanoparticles supported on reduced graphene oxide $\left(\mathrm{CuFe}_{2} \mathrm{O}_{4} / \mathrm{rGO}\right)$ for phenol degradation. Mater Chem Phys 238:121931. https://doi.org/10.1016/j. matchemphys.2019.121931

Otsuka M, Tanabe H, Osaki K, Otsuka K, Ozaki Y (2007) Chemoinformetrical evaluation of dissolution property of indomethacin tablets by near-infrared spectroscopy. J Pharm Sci 96:788-801. https://doi.org/10.1002/jps.20704

Pachamuthu MP, Karthikeyan S, Maheswari R, Lee AF, Ramanathan A (2017) Fenton-like degradation of Bisphenol A catalyzed by mesoporous Cu/TUD-1. Appl Surf Sci 393:67-73. https://doi. org/10.1016/j.apsusc.2016.09.162

Paramo-Vargas J, Granados SG, Maldonado-Rubio MI, Peralta-Hernandez JM (2016) Up to $95 \%$ reduction of chemical oxygen demand of slaughterhouse effluents using Fenton and photoFenton oxidation. Environ Chem Lett 14:149-154. https://doi. org/10.1007/s10311-015-0534-2

Parida K, Dash S, Mallik S, Das J (2005) Effect of heat treatment on the physico-chemical properties and catalytic activity of manganese nodules leached residue towards decomposition of hydrogen peroxide. J Colloid Interface Sci 290:431-436. https://doi.org/10. 1016/j.jcis.2005.04.056

Park CM, Heo J, Yoon Y (2017) Oxidative degradation of bisphenol A and $17 \alpha$-ethinyl estradiol by Fenton-like activity of silver nanoparticles in aqueous solution. Chemosphere 168:617-622. https://doi.org/10.1016/j.chemosphere.2016.11.016

Perathoner S, Centi G (2005) Wet hydrogen peroxide catalytic oxidation (WHPCO) of organic waste in agro-food and industrial 
streams. Topics Catal 33:207-224. https://doi.org/10.1007/ s11244-005-2529-x

Pereira M, Oliveira L, Murad E (2012) Iron oxide catalysts: Fenton and Fentonlike reactions-a review. Clay Miner 47:285-302. https:// doi.org/10.1180/claymin.2012.047.3.01

Pirsaheb M, Moradi S, Shahlaei M, Wang X, Farhadian N (2019) A new composite of nano zero-valent iron encapsulated in carbon dots for oxidative removal of bio-refractory antibiotics from water. J Clean Prod 209:1523-1532. https://doi.org/10.1016/j. jclepro.2018.11.175

Pouran SR, Raman AAA, Daud WMAW (2014) Review on the application of modified iron oxides as heterogeneous catalysts in Fenton reactions. J Clean Prod 64:24-35. https://doi.org/10.1016/j.jclep ro.2013.09.013

Qu Z, Cheng M, Huang W, Bao X (2005) Formation of subsurface oxygen species and its high activity toward $\mathrm{CO}$ oxidation over silver catalysts. J Catal 229:446-458. https://doi.org/10.1016/j. jcat.2004.11.043

Quinn B, Gagné F, Blaise C (2008) An investigation into the acute and chronic toxicity of eleven pharmaceuticals (and their solvents) found in wastewater effluent on the cnidarian Hydra attenuata. Sci Total Environ 389:306-314. https://doi.org/10.1016/j.scito tenv.2007.08.038

Rayaroth MP, Aravind UK, Aravindakumar CT (2016) Degradation of pharmaceuticals by ultrasound-based advanced oxidation process. Environ Chem Lett 14:259-290. https://doi.org/10.1007/ s10311-016-0568-0

Ren Y, Ma Z, Bruce PG (2012) Ordered mesoporous metal oxides: synthesis and applications. Chem Soc Rev 41:4909-4927. https:// doi.org/10.1039/C2CS35086F

Rhadfi T, Piquemal J-Y, Sicard L, Herbst F, Briot E, Benedetti M, Atlamsani A (2010) Polyol-made Mn3O4 nanocrystals as efficient Fenton-like catalysts. Appl Catal A: Gen 386:132-139. https://doi.org/10.1016/j.apcata.2010.07.044

Rigg T, Taylor W, Weiss J (1954) The rate constant of the reaction between hydrogen peroxide and ferrous ions. J Chem Phys 22:575-577. https://doi.org/10.1063/1.1740127

Robinson DM et al (2013) Photochemical water oxidation by crystalline polymorphs of manganese oxides: structural requirements for catalysis. J Am Chem Soc 135:3494-3501. https://doi.org/ 10.1021/ja310286h

Rossi AF, Amaral-Silva N, Martins RC, Quinta-Ferreira RM (2012) Heterogeneous Fenton using ceria based catalysts: effects of the calcination temperature in the process efficiency. Appl Catal B 111:254-263. https://doi.org/10.1016/j.apcatb.2011.10.006

Rueda Márquez JJ, Levchuk I, Sillanpää M (2018) Application of catalytic wet peroxide oxidation for industrial and urban wastewater treatment: a review. Catalysts 8:673. https://doi.org/10.3390/catal 8120673

Rusevova K, Kopinke F-D, Georgi A (2012) Nano-sized magnetic iron oxides as catalysts for heterogeneous Fenton-like reactionsInfluence of $\mathrm{Fe}(\mathrm{II}) / \mathrm{Fe}$ (III) ratio on catalytic performance. J Hazard Mater 241:433-440. https://doi.org/10.1016/j.jhazmat. 2012.09.068

Rusevova K, Köferstein R, Rosell M, Richnow HH, Kopinke F-D, Georgi A (2014) $\mathrm{LaFeO}_{3}$ and $\mathrm{BiFeO}_{3}$ perovskites as nanocatalysts for contaminant degradation in heterogeneous Fenton-like reactions. Chem Eng J 239:322-331. https://doi.org/10.1016/j. cej.2013.11.025

Saeed M, Ahmad A, Boddula R, Ul Haq A, Azhar A (2018) Ag@ $\mathrm{Mn}_{\mathrm{x}} \mathrm{O}_{\mathrm{y}}$ : an effective catalyst for photo-degradation of rhodamine B dye. Environ Chem Lett 16:287-294. https://doi.org/10.1007/ s10311-017-0661-z

Salazar R, Brillas E, Sirés I (2012) Finding the best $\mathrm{Fe}^{2+} / \mathrm{Cu}^{2+}$ combination for the solar photoelectro-Fenton treatment of simulated wastewater containing the industrial textile dye Disperse Blue 3.
Appl Catal B: Environ 115:107-116. https://doi.org/10.1016/j. apcatb.2011.12.026

Salem IA (2000) Kinetics of the oxidative color removal and degradation of bromophenol blue with hydrogen peroxide catalyzed by copper (II)-supported alumina and zirconia. Appl Catal B: Environ 28:153-162. https://doi.org/10.1016/S0926-3373(00) 00173-9

Salimi M et al (2017) Contaminants of emerging concern: a review of new approach in AOP technologies. Environ Monit Assess 189:414. https://doi.org/10.1007/s10661-017-6097-x

Shahidi D, Roy R, Azzouz A (2015) Advances in catalytic oxidation of organic pollutants-prospects for thorough mineralization by natural clay catalysts. Appl Catal B: Environ 174:277-292. https://doi.org/10.1016/j.apcatb.2015.02.042

Shen Y, Zhang Z, Xiao K (2015) Evaluation of cobalt oxide, copper oxide and their solid solutions as heterogeneous catalysts for Fenton-degradation of dye pollutants. RSC Adv 5:91846-91854. https://doi.org/10.1039/C5RA18923C

Shen Y, Zhou Y, Zhang Z, Xiao K (2017) Cobalt-copper oxalate nanofibers mediated Fenton degradation of Congo red in aqueous solutions. J Ind Eng Chem 52:153-161. https://doi.org/10. 1016/j.jiec.2017.03.038

Sigel H (2000) Metal ions in biological systems: volume 37: manganese and its role in biological processes. CRC Press. https://doi. org/10.1021/jm000216b

Singh L, Rekha P, Chand S (2016) Cu-impregnated zeolite Y as highly active and stable heterogeneous Fenton-like catalyst for degradation of Congo red dye. Sep Purif Technol 170:321-336. https:// doi.org/10.1016/j.seppur.2016.06.059

Sirés I, Garrido JA, Rodríguez RM, Centellas F, Arias C, Brillas E (2006) Electrochemical degradation of paracetamol from water by catalytic action of $\mathrm{Fe}^{2+}, \mathrm{Cu}^{2+}$, and UVA light on electrogenerated hydrogen peroxide. J Electrochem Soc 153:D1-D9. https://doi.org/10.1149/1.2130568

Soares PA, Silva TF, Manenti DR, Souza SM, Boaventura RA, Vilar VJ (2014) Insights into real cotton-textile dyeing wastewater treatment using solar advanced oxidation processes. Environ Sci Pollut Res 21:932-945. https://doi.org/10.1007/s11356-013-1934-0

Song $\mathrm{H}$ et al (2016) Manganese functionalized mesoporous molecular sieves Ti-HMS as a Fenton-like catalyst for dyes wastewater purification by advanced oxidation processes Journal of Environmental. Chem Eng 4:4653-4660. https://doi.org/10.1016/j. jece.2016.09.039

Sun Q et al (2017) Synthesis of Fe/M (M= Mn Co, Ni) bimetallic metal organic frameworks and their catalytic activity for phenol degradation under mild conditions. Inorg Chem Front 4:144-153. https://doi.org/10.1039/C6QI00441E

Sun Y et al (2019) Revealing the active species of Cu-based catalysts for heterogeneous Fenton reaction. Appl Catal B 258:117985. https://doi.org/10.1016/j.apcatb.2019.117985

Tang Y, Ren H, Yang P, Li H, Zhang J, Qu C, Chen G (2019) Treatment of fracturing fluid waste by Fenton reaction using transition metal complexes catalyzes oxidation of hydroxypropyl guar gum at high pH. Environ Chem Lett 17:559-564. https://doi.org/10. 1007/s10311-018-0805-9

Tian S, Tu Y, Chen D, Chen X, Xiong Y (2011) Degradation of Acid Orange II at neutral $\mathrm{pH}$ using $\mathrm{Fe}_{2}\left(\mathrm{MoO}_{4}\right)_{3}$ as a heterogeneous Fenton-like catalyst. Chem Eng J 169:31-37. https://doi.org/10. 1016/j.cej.2011.02.045

Tian X, Jin H, Nie Y, Zhou Z, Yang C, Li Y, Wang Y (2017) Heterogeneous Fenton-like degradation of ofloxacin over a wide $\mathrm{pH}$ range of 3.6-10.0 over modified mesoporous iron oxide. Chem Eng J 328:397-405. https://doi.org/10.1016/j.cej.2017.07.049

Tiya-Djowe A, Nzali S, Njoyim ET, Laminsi S, Gaigneaux EM (2016) Thermal treatment of plasma-synthesized goethite improves 
Fenton-like degradation of orange II dye. Environ Chem Lett 14:515-519. https://doi.org/10.1007/s10311-016-0578-y

Trovarelli A, de Leitenburg C, Boaro M, Dolcetti G (1999) The utilization of ceria in industrial catalysis. Catal Today 50:353-367. https://doi.org/10.1016/S0920-5861(98)00515-X

Tušar NN et al (2012) Manganese functionalized silicate nanoparticles as a fenton-type catalyst for water purification by advanced oxidation processes (AOP). Adv Funct Mater 22:820-826. https:// doi.org/10.1002/adfm.201102361

Umar M, Aziz HA, Yusoff MS (2010) Trends in the use of Fenton, electro-Fenton and photo-Fenton for the treatment of landfill leachate. Waste Manage 30:2113-2121. https://doi.org/10.1016/j. wasman.2010.07.003

Vindedahl AM, Strehlau JH, Arnold WA, Penn RL (2016) Organic matter and iron oxide nanoparticles: aggregation, interactions, and reactivity. Environ Sci: Nano 3:494-505. https://doi.org/10. 1039/C5EN00215J

Walling C (1975) Fenton's reagent revisited. Acc Chem Res 8:125-131. https://doi.org/10.1021/ar50088a003

Walling C, Goosen A (1973) Mechanism of the ferric ion catalyzed decomposition of hydrogen peroxide Effect of organic substrates. J Am Chem Soc 95:2987-2991. https://doi.org/10.1021/ja00790a042

Wang J, Zhuan R (2020) Degradation of antibiotics by advanced oxidation processes: an overview. Sci Total Environ 701:135023. https:// doi.org/10.1016/j.scitotenv.2019.135023

Wang Y, Zhao H, Zhao G, Wang Y, Yang X (2013) Iron compound-based heterogeneous Fenton catalytic oxidation technology. Prog Chem 25:1246. https://doi.org/10.7536/PC121201

Wang Y, Zhao H, Zhao G (2015) Iron-copper bimetallic nanoparticles embedded within ordered mesoporous carbon as effective and stable heterogeneous Fenton catalyst for the degradation of organic contaminants. Appl Catal B 164:396-406. https://doi.org/10. 1016/j.apcatb.2014.09.047

Wang N, Zheng T, Zhang G, Wang P (2016) A review on Fenton-like processes for organic wastewater treatment Journal of Environmental. Chem Eng 4:762-787. https://doi.org/10.1016/j.jece.2015.12.016

Wang N, Hao L, Chen J, Zhao Q, Xu H (2018) Adsorptive removal of organics from aqueous phase by acid-activated coal fly ash: preparation, adsorption, and Fenton regenerative valorization of "spent" adsorbent. Environ Sci Pollut Res 25:12481-12490. https://doi.org/ 10.1007/s11356-018-1560-y

Watts RJ, Sarasa J, Loge FJ, Teel AL (2005) Oxidative and reductive pathways in manganese-catalyzed Fenton's reactions. J Environ Eng 131:158-164. https://doi.org/10.1061/(ASCE)07339372(2005)131:1(158)

Weaver J, Frederikse H (1977) Crc handbook of chemistry and physics. CRC Press, Boca Raton 76:12-156 https://doi.org/10.1021/ja069 $813 z$

Wei X, Xie X, Wang Y, Yang S (2020) Shape-Dependent FentonLike Catalytic Activity of $\mathrm{Fe}_{3} \mathrm{O}_{4}$ Nanoparticles. J Environ Eng 146:04020005. https://doi.org/10.1061/(ASCE)EE.1943-7870. 0001648

Wu J, Lin G, Li P, Yin W, Wang X, Yang B (2013) Heterogeneous Fenton-like degradation of an azo dye reactive brilliant orange by the combination of activated carbon- $\mathrm{FeOOH}$ catalyst and $\mathrm{H}_{2} \mathrm{O}_{2}$. Water Sci Technol 67:572-578. https://doi.org/10.2166/wst.2012.596

Wu X, Xia F, Nan Z (2020) Facile synthesis of double-mesoporousshelled hollow spheres of $\mathrm{Cu}-\mathrm{CuFe}_{2} \mathrm{O}_{4} / \mathrm{SiO}_{2}$ composite as excellent Fenton catalyst. Mater Chem Phys 242:122490. https://doi.org/ 10.1016/j.matchemphys.2019.122490

Xia M, Long M, Yang Y, Chen C, Cai W, Zhou B (2011) A highly active bimetallic oxides catalyst supported on Al-containing MCM-41 for Fenton oxidation of phenol solution. Appl Catal B: Environ 110:118-125. https://doi.org/10.1016/j.apcatb.2011.08.033

Xiao W, Wang D, Lou XW (2010) Shape-controlled synthesis of $\mathrm{MnO}_{2}$ nanostructures with enhanced electrocatalytic activity for oxygen reduction. J Phys Chem C 114:1694-1700. https://doi.org/10.1021/ jp909386d

Xie F, Zhong J, Wang L, Wang K, Hua D (2015) Degradation of acid scarlet $3 \mathrm{R}$ with $\mathrm{CuO} / \mathrm{SiO}_{2}$ hollow sphere catalyst. In: IOP Conference Series: Materials Science and Engineering, 1: 012039 https:// doi.org/10.1088/1757-899X/87/1/012039

Xie H, Zeng J, Zhou G (2020) CeCu composite oxide for chlorophenol effective removal by heterogeneous catalytic wet peroxide oxidation. Environ Sci Pollut Res 27:846-860. https://doi.org/10.1007/ s11356-019-07042-5

Xu L, Wang J (2011) A heterogeneous Fenton-like system with nanoparticulate zero-valent iron for removal of 4-chloro-3-methyl phenol. J Hazard Mater 186:256-264. https://doi.org/10.1016/j.jhazmat. 2010.10 .116

$\mathrm{Xu}$ L, Wang $\mathbf{J}$ (2012) Magnetic nanoscaled $\mathrm{Fe}_{3} \mathrm{O}_{4} / \mathrm{CeO}_{2}$ composite as an efficient Fenton-like heterogeneous catalyst for degradation of 4-chlorophenol. Environ Sci Technol 46:10145-10153. https://doi. org/10.1021/es300303f

Xu L, Wang J (2015) Degradation of 2, 4, 6-trichlorophenol using magnetic nanoscaled $\mathrm{Fe}_{3} \mathrm{O}_{4} / \mathrm{CeO}_{2}$ composite as a heterogeneous Fenton-like catalyst. Sep Purif Technol 149:255-264. https://doi.org/ 10.1016/j.seppur.2015.05.011

Xu N, Guo D, Xiao C (2019) Fe/Mn oxide decorated polyacrylonitrile hollow fiber membrane as heterogeneous Fenton reactor for methylene blue decolorization. J Appl Polym Sci 136:48217. https://doi. org/10.1002/app.48217

Xu Y, Guo X, Zha F, Tang X, Tian H (2020) Efficient photocatalytic removal of orange II by a $\mathrm{Mn} 3 \mathrm{O} 4-\mathrm{FeS}_{2} / \mathrm{Fe}_{2} \mathrm{O}_{3}$ heterogeneous catalyst. J Environ Manage 253:109695. https://doi.org/10.1016/j. jenvman.2019.109695

Xue X, Hanna K, Deng N (2009) Fenton-like oxidation of Rhodamine B in the presence of two types of iron (II, III) oxide. J Hazard Mater 166:407-414. https://doi.org/10.1016/j.jhazmat.2008.11.089

Yaman YC, Gündüz G, Dükkancı M (2013) Degradation of CI R eactive $\mathrm{R}$ ed 141 by heterogeneous $\mathrm{F}$ enton-like process over iron-containing ZSM-5 zeolites. Coloration Technology 129: 69-75 https://doi. org/10.1111/cote. 12001

Yang B, Tian Z, Zhang L, Guo Y, Yan S (2015) Enhanced heterogeneous Fenton degradation of Methylene Blue by nanoscale zero valent iron (nZVI) assembled on magnetic $\mathrm{Fe} 3 \mathrm{O} 4 /$ reduced graphene oxide. J Water Process Eng 5:101-111. https://doi.org/10.1016/j. jwpe.2015.01.006

Yang X, He J, Yang Q, Jiao R, Liao G, Wang D (2019) Cu (I)-doped $\mathrm{Fe}_{3} \mathrm{O}_{4}$ nanoparticles/porous $\mathrm{C}$ composite for enhanced $\mathrm{H}_{2} \mathrm{O}_{2}$ oxidation of carbamazepine. J Colloid Interface Sci 551:16-25. https:// doi.org/10.1016/j.jcis.2019.04.083

Zha S, Cheng Y, Gao Y, Chen Z, Megharaj M, Naidu R (2014) Nanoscale zero-valent iron as a catalyst for heterogeneous Fenton oxidation of amoxicillin. Chem Eng J 255:141-148. https://doi.org/10.1016/j. cej.2014.06.057

Zhang X, Ding Y, Tang H, Han X, Zhu L, Wang N (2014) Degradation of bisphenol A by hydrogen peroxide activated with $\mathrm{CuFeO}_{2}$ microparticles as a heterogeneous Fenton-like catalyst: efficiency, stability and mechanism. Chem Eng J 236:251-262. https://doi.org/ 10.1016/j.cej.2013.09.051

Zhang N, Chen J, Fang Z, Tsang EP (2019) Ceria accelerated nanoscale zerovalent iron assisted heterogenous Fenton oxidation of tetracycline. Chem Eng J 369:588-599. https://doi.org/10.1016/j.cej. 2019.03.112

Zhang N, Tsang EP, Chen J, Fang Z, Zhao D (2020a) Critical role of oxygen vacancies in heterogeneous Fenton oxidation over ceria-based catalysts. J Colloid Interface Sci 558:163-172. https://doi.org/10. 1016/j.jcis.2019.09.079

Zhang N, Yi Y, Lian J, Fang Z (2020b) Effects of Ce doping on the Fenton-like reactivity of $\mathrm{Cu}$-based catalyst to the fluconazole. Chem Eng J 395:124897. https://doi.org/10.1016/j.cej.2020.124897 
Zhao G, Li J, Ren X, Hu J, Hu W, Wang X (2013) Highly active $\mathrm{MnO}_{2}$ nanosheet synthesis from graphene oxide templates and their application in efficient oxidative degradation of methylene blue. RSC Adv 3:12909-12914. https://doi.org/10.1039/C3RA40942B

Zhou T, Li Y, Ji J, Wong F-S, Lu X (2008) Oxidation of 4-chlorophenol in a heterogeneous zero valent iron/ $\mathrm{H}_{2} \mathrm{O}_{2}$ Fenton-like system: Kinetic, pathway and effect factors. Sep Purif Technol 62:551-558. https:// doi.org/10.1016/j.seppur.2008.03.008

Zubir NA, Yacou C, Motuzas J, Zhang X, Da Costa JCD (2014) Structural and functional investigation of graphene oxide- $-\mathrm{Fe}_{3} \mathrm{O}_{4}$ nanocomposites for the heterogeneous Fenton-like reaction. Sci Rep 4:4594. https://doi.org/10.1038/srep04594

Publisher's Note Springer Nature remains neutral with regard to jurisdictional claims in published maps and institutional affiliations. 